\title{
Recontextualising the Sacraments: Diego González Holguín's Construction of Christian Vocabulary in Colonial Peru
}

\author{
Sabine Dedenbach-Salazar Sáenz, University of Stirling, Scotland \\ (18 February 2019)
}

Published in:

Dedenbach-Salazar Sáenz, Sabine (ed.). Translating Wor(I)ds: Explaining Christianity across Cultural Boundaries, pp. 157-198. (Collectanea Instituti Anthropos 51.) Baden-Baden: Academia Verlag 2019.

See <https://www.nomos-elibrary.de/10.5771/9783896657954-1/titelei-inhaltsverzeichnis> (accessed 19.0.9.2019).

Sabine Dedenbach-Salazar Sáenz is member the Faculty of Arts and Humanities of the University of Stirling (Scotland). Her research focuses on the (ethno)linguistic and ethnohistorical study of the Andean indigenous languages (mainly Quechua), analysing the translation of culture and the dynamics of religious change, above all in the framework of the encounter and clash of cultures in the early colonial era (see < http://www.dedenbachsalazar.stir.ac.uk/ > [accessed 04.02.2019]).

Her recent publications on the language of Christianisation include:

- Muchay - worshipping God and the huacas: The complex usage of a Quechua word in the colonial Andes. In: Susana Bayó Belenguer, Eiléan Ní Chuilleanáin, Cormac Ó Cuilleanáin (eds.), Translation Right or Wrong; 173-190. Dublin: Four Courts Press 2013. - El Tratado de los errores de Francisco de Ávila en comparación con el manuscrito quechua de Huarochirí. Estudio analítico y transcripción comparativa. St. Andrews: St. Andrews University, Centre for Amerindian, Latin American and Caribbean Studies 2016. (CAS Occasional Publications 34.)

- '... por decir Dios Trino y Uno, dijo Dios tres y uno son cuatro': The Christian Trinity and the Multiplicity of Andean Deities: Indigenous Beliefs and the Instruction of the Christian Doctrine in Quechua. Colonial Latin American Review 25/4 (2016): 414-444.

- Co-authored with Elke Ruhnau: 'Salvando las almas de los indios': Los conceptos de 'alma/ánima' en las lenguas coloniales náhuatl y quechua. Together with Elke Ruhnau. In: Sabine Dedenbach-Salazar Sáenz (ed.), La transmisión de conceptos cristianos a las lenguas amerindias: Estudios sobre textos y contextos de la época colonial; 185-230. Sankt Augustin: Academia Verlag 2016. (Collectanea Instituti Anthropos 48.) < http://hdl.handle.net/1893/22937 > (accessed 04.02.2019).

- Idolatría y sexualidad: Métodos y contextos de la transmisión y traducción de conceptos cristianos en los confesionarios ibéricos y coloniales de los siglos xvi-xviii. Introducción al dossier. In thematic collection: Idolatría y sexualidad: métodos y contextos de la transmisión y traducción de conceptos cristianos en los confesionarios ibéricos y coloniales de los siglos xvi-xviii. Organización: Sabine Dedenbach-Salazar Sáenz. Indiana 35/2 (2018): 9-27. < https://journals.iai.spkberlin.de/index.php/indiana/article/view/2531 > (accessed 04.02.2019). 


\title{
Contents
}

1. Introduction

2. Diego González Holguín and his lexicographical work

3. The sacraments

4. Holy Communion

5. Extreme Unction

6. Conclusion

References

\begin{abstract}
In 1608 the Jesuit missionary-linguist Diego González Holguín published a comprehensive Spanish-Quechua dictionary which covered all aspects of life and also included a wide range of words which refer to Christian and Andean beliefs. Although he situated himself in a by then established Christian Andean tradition of the translation of religious concepts, he also used innovative translation methods, reinterpreting Andean and Christian words in an unorthodox way.
\end{abstract}

Through the analysis of his translation methods light can be shed on the process in which religions are constructed. For this I will examine the translations of the term 'sacrament'. Whilst the word itself is transmitted into Quechua as a loanword, in more detailed explanations the author uses extensions of meanings and metaphorical expressions. Thus, for example, a certain aspect of the sacraments is translated in the context of healing/poisoning; another instance is the relation of the Holy Communion to the powerful royal Inca travel provision. González Holguín's translation approach shows how Christian religion could be integrated into the Andean worldview. [Colonial Peru, Christianisation, Dictionary Source, Quechua language, Sacraments]

\section{Introduction $^{1}$}

When the empire of the Incas was invaded in 1532 and submitted to Spanish rule little later, the newly formed colony received the Crown's right to take care of the conversion of the indigenous population to Christianity. Following earlier efforts in Mesoamerica to translate Christian texts into the native languages and teach the new faith through them, missionary linguists started creating grammars and dictionaries for the most widely spoken languages in order to have a linguistic framework for the translation of the Christian doctrine and related texts. ${ }^{2}$ In Peru the first dictionary and grammar,

$1 \quad$ I would like to thank Lindsey Crickmay and Cândida Barros for their careful reading of this paper and for their suggestions.

2 These grammatical and lexicographic studies were among the first works in descriptive linguistics. 
accompanied by a short Christian text, was published by the Dominican Domingo de Santo Tomás in 1560 (Dedenbach-Salazar Sáenz 2008: 236-237). When the Third Provincial Council met in Lima at the beginning of the 1580s, it was decided, under the direction of the eminent Jesuit scholar José de Acosta, to produce an authoritative catechism in Quechua and Aymara, including a large collection of sermons to be used as models for the preachers who were supposed to have good knowledge of the native language of the area they worked in. These doctrinal works were complemented by a brief grammar and dictionary, from an author who has remained anonymous (Dedenbach-Salazar Sáenz 2008: 237-238). The missionaries worked with these books (and probably other materials of their own) as the basis for their Christian teachings, and only in 1607 and 1608 a further grammar and dictionary were published by the Jesuit missionary and linguist Diego González Holguín. As opposed to the earlier linguistic works these were much more comprehensive and detailed, and the Quechua-Spanish and Spanish-Quechua dictionary can be said to be the most comprehensive until the present. $^{3}$

It covers all aspects of life and also includes a wide range of words which refer to Christian and Andean beliefs (of which the earlier ones only had few). Although González Holguín situated himself in a by then established (although not made explicit) Christian Andean tradition of the translation of religious concepts, I will show that he also used innovative translation methods, reinterpreting Andean and Christian words in an unorthodox way. Through the analysis of his translation methods light can be shed on the process of how Andean and Spanish religion became linked. For this I will examine how he translated the term 'sacrament' as well as how he transmitted the concepts of the Holy Communion and the Extreme Unction. Whilst the words themselves are transmitted into Quechua as loanwords, in phrases and sentences the author uses extensions of meanings and metaphorical expressions which re-contextualise the Christian contents in order to provide explanations the indigenous population would be able to relate to their own cosmovision and experience.

\section{Diego González Holguín and his lexicographical work}

Diego González Holguín, born in Cáceres in 1552, was a member of one of the most distinguished families of Spain. He studied oriental and classical languages as well as the Bible at the Universidad de Alcalá de Henares. Although we have no knowledge of the syllabi of these subjects, we can suppose that, in addition to the languages themselves and the Scripture, students became familiarised with the topics and challenges of translation as this field was well known and widely discussed in Spain at the time (Dedenbach-Salazar Sáenz 2016: 8-10).

3 Except for the one by Jorge Lira, also a priest, who published his 1200-page dictionary in 1944. For further information on the topics of this Introduction see Durston 2007; Mills 2008; Hamerly 2011; Dedenbach-Salazar Sáenz 2016. 
In 1581 González Holguín came to Cuzco as part of a Jesuit mission and was ordained as priest. It was also in the ancient Inca capital that he learned Quechua, the most widespread language due to the Incas' expansion, and consequently he used this dialect in his linguistic works. ${ }^{4}$

In 1600 he became rector of the Jesuit order in La Plata (Sucre, Bolivia), and in 1607 he was superior of the Jesuits in Juli, an important linguistic and missionary centre on Lake Titicaca. He then worked as an advocate for the indigenous population (defensor de indios) in Paraguay and Chile and became rector of the colegio in La Asunción. He died in 1618, while serving as superior of the residencia of Mendoza.

Like the other missionary linguists, González Holguín viewed his work as an aid for the missionaries to learn the indigenous language for the purpose of conversion. It has therefore to be kept in mind that his target group were the missionaries, not the indigenous people who would have been secondary recipients, through the words and teachings of the parish priests.

González Holguín wrote that the Quechua language lacked all kinds of words referring to vices and virtues, to the other life, and to the spiritual sphere, and that his dictionary helped to fill these lacunae ([1608] 1989: Al lector). Here he was obviously thinking of these concepts as part of the Christian faith because his work shows that most of these concepts were, indeed, present in the Quechua language, but not their exact Christian equivalents. The dictionary is a veritable treasure-trove of Quechua words and phrases, which is not surprising in the light of the author's statement that the principal authors were all the Indians whom he had consulted and with whom he had worked for many years (ibid.: Al christiano lector). Whilst all dictionaries of the time were to a certain extent modelled on Nebrija's first Spanish dictionary, González Holguín also used the Quechua vocabulary written in the context of the Third Lima Council as the basis for his work, supplementing it with a great deal of additional material and much more elaborated and detailed entries. The contents of his dictionary include words from virtually every sphere of human life and Andean culture, as well as the mentioned Christian terms. The first part, Quechua-Spanish, is comprised of 372 pages; the second part, SpanishQuechua, contains 330 pages (in the original 1608 edition). There are approximately 25,000 entries altogether.

When studying individual words, it becomes clear that González Holguín constructed a network of words and meanings which could be cross-referenced and used as a manual to learn Quechua and deepen the missionaries' knowledge in text and context. $^{5}$

$4 \quad$ The following paragraphs summarise mainly Dedenbach-Salazar Sáenz 2008: 238-239; cf. Mannheim 2008.

5 See for example the semantic field of muchay, 'to worship' (Dedenbach-Salazar Sáenz 2013: 238-246).

I use the consistent modern phonemic official Cuzco orthography when discussing lexical and morphological items; thus, for example, different spellings for what are the phonemes and their modern graphic representations /k/, /k', /kh/ and /q/, /q'/, 
Even apparently straightforward semantic fields, such as the one around maki, 'hand', show that his dictionary hardly ever has one-word entries and equivalents, but in this case for instance ca. 122 equivalents, explanations and examples, concrete as well as figurative expressions. The translations and phrases document the richness of Cuzco Quechua as well as the challenge of incorporating new aspects into the indigenous languages as a result of the colonial situation.

\section{The sacraments}

The Tercero Cathecismo ${ }^{6}$, a collection of sermons published by the Third Lima Council in 1585, says that the sacraments are the signs and ceremonies ordered by Jesus Christ, with which we honour God and take part in his grace, and that those who take them are free from $\sin ^{7}$ González Holguín himself has an example of a Quechua translation for this:

Remedios para los pecados son los sacramentos. Huchacuna pampachaypac sacramentocunam yachacupuquen casca. ${ }^{8}$ (1608, Sp-Qu: 294; 1989: 657) The sacraments are remedies for the sins [Spanish]. The sacraments were means/remedies to forgive the sins (Christian usage) / lit. For the faults to become even the sacraments were remedies [Quechua]. (Transl. SDS ${ }^{9}$ )

/qh/ were used in the colonial sources, e.g. $\{q u\},\{q q u\},\{c\},\{c c\},\{k\} ;$ or $\{e\}$ and $\{i\}$ for the phoneme /i/.

Accompanying doctrinal texts (Doctrina Christiana [1584] 1985), this is the first collection of sermons, published in Spanish with translations into Quechua and Aymara, in 1585, by the Third Lima Council (Tercero cathecismo 1985). The underlying content and model for these would have been the catechism laid down by the Council of Trent in 1566 (see Catechism of Trent [1566] 1823, Catechismvs ex decreto Concilii Tridentini, ad parochos 1572), also known as Roman Catechism.

7 "Sacramentos llamamos vnas señales y cerimonias ordenadas por lesu Christo: con las cuales honramos a Dios y participamos de su gracia. ... los Sacramentos ... hazen que los que los toman queden libres de peccado" (Tercero Cathecismo, sermón X [1585: fol. 56v-57r], 1985: 460-461).

"Yachacupuquen" is given by González Holguín as 'the means, o medication, or what is important and valuable for something' ("Los medios, o remedios, o lo que importa y vale para algo", 1608, Qu-Sp: 362; 1989: 361); the religious meaning of pampacha- is a colonial creation (1608, Qu-Sp: 274, González Holguín 1989: 276; Dedenbach-Salazar Sáenz 2013: 294). The nominalised form kasqa as a past tense was probably constructed by González Holguín and/or other colonial linguists, without reflecting actual Quechua usage (Dedenbach-Salazar Sáenz 1999a).

$9 \quad$ All English translations of ethnohistorical sources and Quechua linguistic materials are mine. My translations from Quechua are based on colonial and modern Quechua dictionaries (González Holguín [1608] 1989; Lira 1944; Perroud and Chouvenc ¿1969?). 
In the Roman Catholic Church the seven sacraments are Baptism, Confirmation, Eucharist, Penance, Extreme Unction, ${ }^{10}$ Holy Orders and Matrimony. ${ }^{11}$

By the beginning of the 17th century, in Christian Quechua the accepted word for 'sacrament' was the loanword itself. ${ }^{12}$ It is therefore not surprising that González Holguín does not include an entry in his dictionary, but that he does, indeed, see the necessity to complement it with words and phrases in the Andean language so that the concepts can be conveyed in an understandable manner to the indigenous people.

Here he follows the Christian imagery for the sacraments: their administration is compared to the preparation and eating of food; the soul can be healed with the sacraments; and the Holy Communion is conceived of as ingesting Christ's body (in the Catholic faith, the direct belief in the Eucharist as the consumption of Christ's body and blood), which is the Lamb of God. Thus, these comparisons and metaphors are what González Holguín had to transmit to the Andean people in their own language. For this, he included in his dictionary example phrases with Christian key words; these already had an Andean meaning which he now embedded in a Christian context in order to convey the new meanings.

10 Now called Anointing of the Sick (Catechism of the Catholic Church 2003, pt. 2, sect. 2, ch. 2, art. 5, 1512, http://www.vatican.va/archive/ccc css/archive/catechism/p2s2c2a5.htm\#, 1499).

11 Doctrina Christiana, Catecismo Mayor, de los Sacramentos [1584, fol. 46r], 1985: 111; cf. Catechism of Trent ([1566] 1823, pt. II, On the Sacraments: 107). Cf. Durston (2007: 277-279).

12 The Third Lima Council had already included a translation of the sacraments into Quechua in the Christian doctrine (Doctrina Christiana, Catecismo mayor [1584: fol. 45v-56v], 1985: 110-132; the Communion [fol. 48r-49v], pp. 115-118), and in the Tercero Cathecismo it also had several sermons which were dedicated to a more detailed explanation (sermon X-XVII [1585] 1985). These translations always use the Spanish loanword. 


\section{A Preparation for the sacraments}

\begin{tabular}{|c|c|c|}
\hline & $\begin{array}{l}\text { González Holguín } \\
\text { (1608, Sp-Qu: 13-14; 1989: 388) } \\
\text { Spanish } \\
\text { Quechua } \\
\text { Spanish in Quechua text in } \\
\text { italics } \\
\text { Added by González Holguín in } \\
\text { the Qechua translation }\end{array}$ & $\begin{array}{l}\text { Translation by SDS } \\
\text { From Spanish (S) } \\
\text { From Quechua (Q) }\end{array}$ \\
\hline 1 & $\begin{array}{l}\text { Adereçar las armas. } \\
\qquad \begin{array}{l}\text { Auccanacunacta, } o \\
\text { auccancacunacta }^{13} \\
\text { huallparicuni }^{14} \text { camaricuni } \\
\text { yachachicuni. }\end{array}\end{array}$ & $\begin{array}{l}\text { To prepare the weapons (S). } \\
\text { With weapons I provide } \\
\text { myself, make myself ready, } \\
\text { prepare myself }(\mathrm{Q}) \text {. }\end{array}$ \\
\hline 2 & $\begin{array}{l}\text { Adereçarse para entrar en la guerra. } \\
\text { Auccaman huallparicuni } \\
\text { yachachicuni. }\end{array}$ & $\begin{array}{l}\text { To prepare oneself to enter war (S). } \\
\text { I equip myself, make myself } \\
\text { ready for the war (Q). }\end{array}$ \\
\hline 3 & $\begin{array}{l}\text { Adereçar cossa suya, o parejarla } \\
\text { aprestarla. } \\
\qquad \text { Allichacuni camaricuni. }\end{array}$ & $\begin{array}{l}\text { To prepare one's own things, or to } \\
\text { put in place, to make ready (S). } \\
\text { I prepare myself, I dispose } \\
\text { myself }(Q) \text {. }\end{array}$ \\
\hline 4 & $\begin{array}{l}\text { Adereçarse assi. } \\
\qquad \begin{array}{l}\text { Allichaycucuni yachachiycucuni } \\
\text { camariycucuni } \\
\text { sacramentocunapac. }\end{array}\end{array}$ & $\begin{array}{l}\text { To prepare oneself like this (S). } \\
\text { I prepare myself, I make } \\
\text { myself ready, I dispose } \\
\text { myself for the sacraments } \\
\text { (Q). }\end{array}$ \\
\hline
\end{tabular}

In order to translate and explain the preparation for the sacraments González Holguín's method is that of a word-for-word translation of Quechua equivalents for Spanish words $(1-3)$. The general usage of the synonymous verbs for 'to prepare' ${ }^{, 15}(3)$ is preceded by

13 González Holguín seems to use the more modern form -na interchangeably with the older form -nqa to express the instrumental (cf. González Holguín [1607] 1975, I. II, cap. 14: fol. $44 r-$ as gerund), both forms for instruments or people dedicated to battle or war (Lira 1944: 72).

$14-n i$ is the suffix for the first person singular, and the colonial dictionaries used it where in Spanish they employed the infinitive.

15 González Holguín gives four largely synonymous verbs for 'to prepare': allichaku-, lit. 'to make oneself good', from allin, 'good', -cha 'to make (the quality of the adjective) - the word generally used for 'to prepare' (also present in the earlier 
examples used for weapons and war (1-2), an important part of the expansionist Inca empire (D'Altroy 2015: ch. 10). These equivalents are then also applied to the Christian concept of the Sacrament which he only gives in the Quechua translation (4) - it seems that as priest he took it apparently for granted that these verbs could also be applied to a religious concept.

The constructions with the objects in question - direct object -ta for the weapons which are prepared (1), indirect object/directional -man for the war one prepares for (2), and -paq benefactive for the object of the purpose, the sacraments (4) - reflect his knowledgeable and consistent usage of Quechua morphology. I doubt whether the sacrament would here necessarily be seen in a context of warfare because this only seems to be an example, although the catechism of Trent talks about confirmation as equipping the Christian "for battle". ${ }^{16}$ In any case it is possible for the missionary Quechua learner to relate both, the war and the Christian concept, in order to remember different grammatical constructions.

Thus in this case González Holguín gives word-for-word equivalents, and except for using a Spanish loanword in the last phrase without explaining it, ${ }^{17}$ by employing everyday Quechua words González Holguín integrates a Christian activity into Andean life as one more aspect of it. ${ }^{18}$

dictionaries of Anonymous 1586 s.v. "adereçar" and "allichacuni", and Santo Tomás [1560: fol. 108v] 1951: 233); kamariku-, 'to get ready, to dispose oneself' (González Holguín 1608, Qu-Sp: 39; 1989: 47); wallpariku-, 'to prepare oneself well adorned or clothed', from wallpa-, 'to make, form' (ibid. 1608, Qu-Sp: 172, 1989: 174); yachachiku-, 'to prepare oneself practicing', lit. 'to teach oneself' (ibid. 1608, Qu-Sp: 362, 1989: 361) (from yacha-, 'to know', yachachi-, 'to teach'; -ri indicates the beginning of an action [González Holguín [1607] 1975, I. III, cap. II: fol. 115v]); -ku as reflexive and pseudo-reflexive modal suffix expresses the subject's involvement in the action (Hoggarth 2004: 38-39; cf. González Holguín [1607] 1975, I. III, cap. II: fol. 111v-112r). Quoting Pope Melchiades, to be understood as the battle against sin or the devil (Catechism of Trent [1566] 1823, On the Sacrament of Confirmation: 139). As the word "sacramentocunapac" is added at the end, it seems to be an afterthought - syntactically one would expect it to be at the beginning of the sentence (but this is, of course, a dictionary, not a sermon).

Obviously, there are many studies on translation methods which vary considerably in terminology and scope of each discussed phenomenon. Here I have used terms which I find most apt for my purpose. I have found the following works particularly useful: Baker 1992: 13-42; Fawcett 1997: ch. 4; Hatch \& Brown 1995: 170-185. 
B The preacher as the one who feeds the soul God's word

\begin{tabular}{|c|c|c|}
\hline & $\begin{array}{l}\text { González Holguín } \\
\text { (1608, Qu-Sp: 129; 1989: 388) }\end{array}$ & Translation by SDS \\
\hline & $\begin{array}{l}\text { Qechua } \\
\text { Spanish in Quechua text in } \\
\text { italics } \\
\quad \text { Spanish }\end{array}$ & From Quechua (Q) \\
\hline 1 & $\begin{array}{l}\text { Karani. } \\
\qquad \begin{array}{l}\text { Dar de comer a personas, } \\
\text { pensar las bestias y aues. ... }\end{array}\end{array}$ & $\begin{array}{l}\text { I serve food / I feed (Q). } \\
\text { To serve food to people, } \\
\text { to feed animals and birds (S). }\end{array}$ \\
\hline 2 & $\begin{array}{l}\text { Karacuk. } \\
\qquad \text { Los que siruen a la mesa. }\end{array}$ & $\begin{array}{l}\text { The one who serves food }(\mathrm{Q}) \text {. } \\
\text { The ones who serve at the } \\
\text { table (S). }\end{array}$ \\
\hline 3 & $\begin{array}{l}\text { Karani animacta Diospa siminhuan o } \\
\text { Sacramentocunahuan, animacta } \\
\text { karak padre. } \\
\text { El predicador. }\end{array}$ & $\begin{array}{l}\text { I feed the soul with / I serve the soul } \\
\text { God's word, or the Father who } \\
\text { feeds the soul with the sacraments } \\
\text { (Q). } \\
\text { The preacher (S). }\end{array}$ \\
\hline
\end{tabular}

In the case of qara-, 'to serve food' (1-2), González Holguín adopts the same method, but in his example of Christian usage he creates a complex and explanatory description of the priest as administrator of the sacraments (3). As above, González Holguín does not coin words or new lexical meanings (neologisms), but embeds accepted Andean words with their original meaning in sentences with Spanish loanwords in order to convey the figurative sense. He combines an everyday cultural concept, 'to serve food, to feed', with a more specified action where metaphorically the soul is fed with God's word, and the priest feeds the sacraments to the soul. ${ }^{19}$ This construction indicates that the indirect target person was meant to know the Spanish words 'soul', 'Father', 'God' and 'sacrament'; and that González Holguín considered the administration of the sacraments to be a vital part of a priest's tasks. In the same way as the Quechua word in this entry becomes related to a Christian concept, this concept is embedded in an Andean understanding. Thus in his Quechua explanation he creates a metaphor - a figurative expression, an image which goes beyond the word's daily usage (Braak 1969: 30-32) -, around the loanword, using understandable semantic resources of the target language to embed it.

19 González Holguín seems to have taken this image from the Catechism of the Council of Trent where the Eucharist is described as follows: "The sacrament is to be used by us as the food and nourishment of our souls." (Catechism of Trent [1566] 1823, On the Sacrament of the Eucharist: 160). 
Finally it should be noted that surprisingly in the translation the function of the priest is not, as described in the Quechua sentence, an administrator of the sacraments. Rather, González Holguín renders the whole sentence simply as 'the preacher'.

\section{Healing, poisoning and the administration of the sacraments}

\begin{tabular}{|c|c|c|}
\hline & $\begin{array}{l}\text { González Holguín } \\
\text { (1608, Qu-Sp: 138-139; 1989: 145) }\end{array}$ & Translation by SDS \\
\hline & $\begin{array}{l}\text { Qechua } \\
\text { Spanish in Quechua text in } \\
\text { italics } \\
\quad \text { Spanish }\end{array}$ & From Spanish (S) \\
\hline 1 & $\begin{array}{l}\text { Hamppi, o hamppicuna. } \\
\text { Qualquiera medicina.... }\end{array}$ & $\begin{array}{l}\text { Medicine, or medicines (Q). } \\
\text { Any medicine (S). }\end{array}$ \\
\hline 2 & $\begin{array}{l}\text { Hampicamayoc. } \\
\text { El médico o cirujano. }\end{array}$ & $\begin{array}{l}\text { The one who is in charge of / } \\
\text { knows about medicine; healer (Q). } \\
\text { The doctor or surgeon (S). }\end{array}$ \\
\hline 3 & $\begin{array}{l}\text { Hampipayani. } \\
\text { Curar de limosna, o de } \\
\text { gracia.... }\end{array}$ & $\begin{array}{l}\text { I assist the healing process / I heal } \\
\text { repeatedly (Q). } \\
\text { To heal with the help of } \\
\text { alms, or out of kindness. (S) }\end{array}$ \\
\hline 4 & $\begin{array}{l}\text { Hampik. } \\
\qquad \begin{array}{l}\text { Es el que dà rexalgar, } \\
\text { o bocado para matar. ... }\end{array}\end{array}$ & $\begin{array}{l}\text { The healer (Q). } \\
\text { The one who gives poison, } \\
\text { or a serving in order to kill } \\
\text { (S). }\end{array}$ \\
\hline 5 & $\begin{array}{l}\text { Hampini, o, hampipayani animacta } \\
\text { huchanmanta } \\
\text { sacramentocunahuan. } \\
\text { Curar al alma de sus pecados } \\
\text { con los sacramentos. }\end{array}$ & $\begin{array}{l}\text { I heal, or repeatedly heal the soul } \\
\text { with the sacraments from its } \\
\text { fault(s) (Q). } \\
\text { To heal the soul from its } \\
\sin (\mathrm{s}) \text { with the sacraments } \\
\text { (S). }\end{array}$ \\
\hline 6 & $\begin{array}{l}\text { Hampipayak. } \\
\text { El sacerdote médico. }\end{array}$ & $\begin{array}{l}\text { The one who assists the healing } \\
\text { process / heals repeatedly (Q). } \\
\text { The doctor priest (S). }\end{array}$ \\
\hline 7 & $\begin{array}{l}\text { Hampini. } \\
\qquad \text { Curar a otro con medicinas. } \\
\ldots\end{array}$ & $\begin{array}{l}\text { I heal (Q). } \\
\text { To heal someone else with } \\
\text { medicine(s) (S). }\end{array}$ \\
\hline
\end{tabular}


The verb hampi- is the most general term for 'to heal' in Quechua. Entries 1 and 7 are straightforward word-for-word equivalents of 'medicine' and 'to heal' (hampi commonly refers to herbal medicine, and the healer is the hampiq; see Marzal 1971: 264-265).

Like most Quechua concepts, hampi(-) can express the positive action of healing as well as the reverse: causing damage through poisoning. ${ }^{20}$ It is therefore understandable that González Holguín has derivations from the term for both (1-3 vs. 4).

Whilst these are all Andean concepts translated by González Holguín, his other entries integrate Christian concepts and thereby extend the Quechua meaning, that of a 'healer' to that of 'priest' (6, also 5).

In Christian faith, Christ is seen as healer of body and soul, ${ }^{21}$ and through the Holy Spirit the sacraments have healing force. It is therefore comprehensible that the Quechua terms for 'medicine/to heal/healer', hampi-/hampiq are used by González Holguín in this context and furter extended to the priest $(5,6)$. This reflects the Christian idea of the confessor as a medical doctor (Muguruza 2018: 36-37) who heals the soul with the sacraments (5). ${ }^{22}$ Besides the priest as healer from the sins $(5,6)$, González Holguín also refers to that of a gesture of benevolence, typical of the Christian behavioural code to give alms (3). ${ }^{23}$

20 In Quechua cosmovision everything has two sides: a positive or benign one as well as a dangerous or negative one. This can be seen in the behaviour of the spirits and deities towards human beings, depending on how they are treated (Dedenbach-Salazar Sáenz 2017: 445), and it is also found in Quechua words, such as ayni- which refers to mutual help, but also to vengeance, i.e. mutual compensation, positive as well as negative (see González Holguín 1608, Qu-Sp: 32-33, 1989: 40).

21 "... the Sacraments bring, to use the words of St. Ambrose, the healing remedies and medicines, as it were, of the Samaritan mentioned in the Gospel." (Catechism of Trent [1566] 1823, pt. II, On the Sacraments: 104, cf. 112). In a dictionary of the lingua geral (Brazil) from 1622, probably written by a Jesuit, 'Father' is translated as pajé, a shaman in Tupí culture (Ayrosa ed. 1938: 324; cf. Monserrat and Barros 2018, section 3 for pajé; I would like to thank Cândida Barros for calling my attention to this parallel). We do not know if there was any communication within the Jesuit order as to the kind of translation of key concepts, or whether the indigenous understanding seemed to make the missionary-linguists create the parallel independently. Supporting the latter hypothesis, Bertonio ([1612] 1984: Sp-Ay: 442-443), another Jesuit, has in his Peruvian Aymara dictionary a different translation of 'Father'/'priest', as 'father' and 'someone who helps another person as if he was a father'. This, then, reflects a rather broad, probably individual, variety of translation methods.

$23 \quad$ For example, "The pastor will teach that every species of satisfaction is included under these three heads, prayer, fasting, and alms-deeds, which correspond with these three sorts of goods, those of the soul, of the body, and what are called external goods, all of which are the gifts of God." (Catechism of Trent [1566] 1823, On the Sacrament of Penance: 204). 
In the Andes healing is carried out by persons with particular knowledge and/or supernatural gifts (Marzal 1971: 257-266) - in this sense the concept of the priest as healer is not far removed from the Andean idea, and although in the late Incaic and early colonial era their denominations and functions varied according to regions, an important task of an Andean priest was healing, mostly through the communication with deities and spirits, and often preceded by divination. ${ }^{24}$

The Quechua suffix -paya which refers to an intensive or repeated action or assistance $^{25}(3,56)$ is apparently used to extend the original meaning to include new aspects. It is therefore possible that González Holguín used morphological devices to create semantic extensions (although words with -paya already had a meaning in Quechua).

It is not completely clear what González Holguín means with the translation: "Hampicamayoc. El médico o cirujano" (2). ${ }^{26}$ An Andean healer is not considered a surgeon who would operate on a person or cut open wounds and tumours. ${ }^{27}$ Whilst a hampiq in charge of a surgeon's task in addition to his traditional ones might have been conceivable as an innovation, the application of the word for an indigenous healer to a 'priest' would certainly have enabled Andean people to integrate the concept of the priest into their own system - certainly a dangerous suggestion from the Christian point of view. Also, at least the Quechua-learning priest (if not the Quechua speaker as well when confronted with these terms in their extended meaning) may have been confused as to the complexity of hampi- which could have been understood in a number of ways: the hampiq is a priest and a doctor; the sacraments help to heal an illness; the healer can be Andean; he can be a surgeon; and hampi- could even refer not to curing, but to poisoning. It is possible that González Holguín's consultants were responsible for these translations and examples, but there is still the fact that he did not disambiguate them and therefore made them available to the missionaries as double entendres, although he wanted to help them to find their way into Andean usage.

All this shows González Holguín's competence in Quechua semantics and grammar, but these examples also reflect how his translation of words and phrases may have caused (con)fusion.

Gareis (1987: 223-275). In more recent times the so-called paqu or altomisayuq heals by communicating with the spirit and deities (Dedenbach-Salazar Sáenz 2017: 448). Whether the hampiq ever communicated with the deities may be doubted; rather he seemed to treat the sick using herbal medicines (Guaman Poma [ca. 1615] 2001: 192 [194]). González Holguín [1607] 1975, I. III, cap. II: fol. 114v. -kamayuq was used to refer to a professional of the task described in the word itself (e.g. González Holguín 1608: 40, 1989: 48). Almost 50 years earlier Santo Tomás ([1560: 136v], 1951: 290) had hampikamayuq as "medico, o cirujano generalmente", 'doctor or surgeon in general'. As described in the Diccionario de Autoridades [1729/II] 1990/1: 360, s.v. cirugia. 
The only two sacraments he explains in his dictionary are those of the Communion and the Extreme Unction, and we will see González Holguín's innovativeness in his entries for these.

\section{Holy Communion}

In the Christian faith, the Lamb of God is the representation of the sacrifice of Jesus Christ in the Eucharist. By dying on the cross he took on humanity's sins in order for all of them to be absolved: "The next day, he saw Jesus coming towards him and said, 'Look, there is the lamb of God that takes away the sin of the world."' ${ }^{28}$ In Christian belief this is the only sacrifice ${ }^{29}$ How does González Holguín express this ritual of the Communion in the Eucharist?

$28 \quad$ New Jerusalem Bible 2015, John 1: 29, http://www.catholic.org/bible/book.php?id=50\&bible chapter=1); "Altera die vidit loannes lesum venientem ad se,\& ait: Ecce agnus Dei, ecce qui tolit peccatum mundi" (Biblia Sacra Vulgatae 1592: 940). This gesture itself represented and replaced the sacrifice of a lamb which, according to the Old Testament, was offered in order to save the people from their sins (e.g. Ezekiel 46, where different animals were to be offered, the most important feature being that they were unblemished ([ibid.

http://www.catholic.org/bible/book.php?id=33\&bible chapter=46; cf. Biblia Sacra Vulgatae 1592: 756]; cf. also for example Leviticus 23: 12 [New Jerusalem Bible 2015, http://www.catholic.org/bible/book.php?id=3\&bible chapter=23; cf. Biblia Sacra Vulgatae 1592: 97]). 176). Cf. the modern Catechism: "The only perfect sacrifice is the one that Christ offered on the cross as a total offering to the Father's love and for our salvation." (2003, pt. 3, sect. 2, ch. 1, art. 1, The first commandment, 2100, http://www.vatican.va/archive/ccc css/archive/catechism/p3s2c1a1.htm\#2099). 


\begin{tabular}{|c|c|c|}
\hline & $\begin{array}{l}\text { González Holguín } \\
\text { (1608, Qu-Sp: 218; 1989: 145) }\end{array}$ & Translation by SDS \\
\hline & $\begin{array}{l}\text { Quechua } \\
\text { Spanish in Quechua text in } \\
\text { italics } \\
\quad \text { Spanish }\end{array}$ & From Quechua (Q) \\
\hline 1 & $\begin{array}{l}\text { Machhicani, } \\
\text { o machhicahuanmi, } \\
\text { o machiycuni, } \\
\text { o machhiycuhuanmi, } \\
\text { o mizquihuanmi, } \\
\text { o miyzquihuanmi [sic], } \\
\text { o mizquichicuni. } \\
\text { Gustar de vna comida saber } \\
\text { bien tomar gusto en ella } \\
\text { como. }\end{array}$ & $\begin{array}{l}\text { I like (the) food, } \\
\text { or the food tastes well for me, } \\
\text { or I enjoy the food, } \\
\text { or it tastes well especially for me, } \\
\text { or it tastes delicious for me, } \\
\text { or it tastes delicious for me, } \\
\text { or I make it taste delicious (Q). } \\
\text { To like a dish, a dish to taste } \\
\text { well, to find it enjoyable, like } \\
\text { (S): }\end{array}$ \\
\hline 2 & $\begin{array}{l}\text { Sanctissimo Sacramentoctam } \\
\text { mizquichicuni machhicacuni, } \\
\text { o Diospa vcunñam machhicuhuan, } \\
\text { o machiycuhuan, } \\
\text { o mizquiycuhuan. } \\
\text { Gusto ya mucho de comulgar. }\end{array}$ & $\begin{array}{l}\text { I find the Holy Sacrament delicious, I } \\
\text { like very much how it tastes, } \\
\text { or God's interior/body already } \\
\text { makes me enjoy it, } \\
\text { or I enjoy it intensively, } \\
\text { or I find it delicious (Q). } \\
\text { I like it very much to receive } \\
\text { Communion (S). }\end{array}$ \\
\hline
\end{tabular}

As mentioned above, the sacraments are seen as food for the soul; it is therefore not surprising that the concept of taste is related to the Eucharist, the Holy Sacrament, as well. The verb González Holguín uses in this instance is "mach(h)i-" which means 'to taste well' ${ }^{30}$, and miski is 'sweet', 'delicious' $(1)^{31}$, which he incorporates into a sentence that can be considered metaphorical - a figurative sweetness of the Eucharist - and at the same time physical with respect to the taste of the bread and wine. Thus the sentence can be seen as a word-for-word translation and a metaphorical expression. The loanword Sanctissimo Sacramento, embedded in Quechua morphology, is explained in the following clause: "God's interior/body [subject] already makes me enjoy it" which seems to be grammatically incorrect as what is enjoyed is God's body (it would have to be: "Sacramento Diospa vcunñatam machhicuhuan”, 'The sacrament makes me enjoy

30 It may derive from Aymara (Bertonio [1612] 1984, Ay-Sp: 211), or both Quechua and Aymara from some older form; the Anonymous dictionary (1586) has 'to become soft, tasty' for (s.v.) "machitmani".

31 -wan is the transitional form to mark third person subject to first person object: 'he/she/it (to) me' (González Holguín [1607] 1975, I. II, cap. XL: fol. 76r). 
God's interior/body [object]'), because it is not God's body which makes one enjoy the sacrament (2). This was a confusing way to explain the concept.

But on the whole we can see how the Holy Communion, central element of which is the ingestion of the Host, ${ }^{32}$ is compared to delicious food, and the mention of God at the same time guarantees that it is related to spiritual enjoyment. ${ }^{33}$ If this was taught comprehensibly to the new flock, it would have been difficult for the indigenous people to compare this kind of ritual to their own kind of offerings where the communication with the deity was the main objective (as it is still today, e.g. Pachamama, in Gow and Condori eds. 1976: 5-12), whereas here it is the ingestion of this deity. Thus, it seems that in these sentences little or no explicit relation is established between Andean and Christian rituals.

So far we have seen word-for-word translations, loanwords, extensions of meaning and metaphorical expressions as the means González Holguín uses to translate Christianity and to a certain degree enable it to be amalgamated. However, a fusion ${ }^{34}$ becomes more evident and explicit in González Holguín's explanation of the Communion when he relates it with the Inca concept of travel provisions.

32 "In St. John he also says: 'The bread that I will give is my flesh, for the life of the world:' [footnote: John vi.52] the bread which he promises to give, he here declares to be 'his flesh'. A little after he adds: 'Unless you eat the flesh of the Son of Man, and drink his blood, you shall not have life in you:' [footnote: john vi.54] and again, 'My flesh is meat indeed, and my blood is drink indeed' [footnote: John vi.56]." (Catechism of Trent [1566] 1823, On the Sacrament of the Eucharist: 161).

33 When chewing coca people will say that it is sweet (Lindsey Crickmay, personal communication, 17 January 2017), and contemporary offerings include different kinds of sweets, e.g. "tulsi mesa", 'sweet table' (from Spanish) (Fernández Juárez 1997: 89-90).

34 'Amalgamate' implies "the forming of a close union without complete loss of individual identities"; 'fuse' "oneness and indissolubility of the resulting product" (Merriam Webster Thesaurus 2018: https://www.merriamwebster.com/thesaurus/fuse [accessed 02.03.2018]). 
E The Holy Communion is the Inca's travel provision

\begin{tabular}{|c|c|c|}
\hline & $\begin{array}{l}\text { González Holguín } \\
\text { (1608, Qu-Sp: 348; 1989: 347) }\end{array}$ & Translation by SDS \\
\hline & $\begin{array}{l}\text { Quechua } \\
\qquad \begin{array}{l}\text { Spanish } \\
\text { Quechua in Spanish text } \\
\text { underlined }\end{array}\end{array}$ & $\begin{array}{l}\text { From Quechua (Q) } \\
\qquad \text { From Spanish (S) }\end{array}$ \\
\hline 1 & $\begin{array}{l}\text { Tupacochor. } \\
\text { Plancha de oro y piedras } \\
\text { engastadas en que se ponia } \\
\text { la mazca paycha que era la } \\
\text { borla, que con tupa cochor } \\
\text { hazian la corona Real del } \\
\text { Inca. }\end{array}$ & $\begin{array}{l}\text { Royal device (Q). } \\
\text { Plate made of gold and inlaid } \\
\text { stones on which the mazca } \\
\text { paycha was set which was } \\
\text { the tassel, which, together } \\
\text { with the tupa cochor } \\
\text { composed the Inca's royal } \\
\text { crown (S). }\end{array}$ \\
\hline 2 & $\begin{array}{l}\text { Tupa yauri. }^{36} \\
\text { El cetro real vara insignia } \\
\text { real del Inca. }\end{array}$ & $\begin{array}{l}\text { Royal sceptre (Q). } \\
\text { The royal scepter, the staff, } \\
\text { the royal insignia of the Inca } \\
\text { (S). }\end{array}$ \\
\hline 3 & $\begin{array}{l}\text { Tupa. } \\
\text { Dize cosa Real que toca al } \\
\text { Rey. }\end{array}$ & $\begin{array}{l}\text { Royal, noble (Q). } \\
\text { Means something royal } \\
\text { which is of the Inca. }\end{array}$ \\
\hline
\end{tabular}

35 Q'uchuy, 'amusement', or qhuchu, 'meeting' (Lira 1944: 415 “"kochoy” and p. 539 "kkhocho" resp.) - but none of these seems to be related to González Holguín's expression, and I have not been able to locate the word in a chronicle. Lafone Quevedo (1892: 334) mentions the word with a question mark and seems to refer to Mossi's dictionary.

36 This and related expressions, including "mazca paycha", with information about different colonial sources, are presented by Araníbar (1995: 396-397, 318) in his index to Pachacuti's chronicle. 


\begin{tabular}{|c|c|c|}
\hline 4 & $\begin{array}{l}\text { El viatico real, la comida que } \\
\text { daua el Rey a los que } \\
\text { embiaua, que era vna talega } \\
\text { de mayz pequeña que por } \\
\text { ser del Rey era de gran } \\
\text { sustento porque vn grano } \\
\text { quitaua la hambre, y comian } \\
\text { vn grano al dia y hauian de } \\
\text { boluer sin acabarse el } \\
\text { viatico. }\end{array}$ & $\begin{array}{l}\text { Royal travel provisions / victuals } \\
\text { (Q). } \\
\text { The royal travel provisions / } \\
\text { Eucharist, the food the King } \\
\text { gave to those he sent, which } \\
\text { was a small sack of maiz, } \\
\text { which - as it was from the } \\
\text { King - was of great } \\
\text { sustenance because one } \\
\text { grain took the hunger away, } \\
\text { and they used to eat one } \\
\text { grain a day and had to come } \\
\text { back without having finished } \\
\text { the provisions / Eucharist } \\
\text { (S). }\end{array}$ \\
\hline 5 & $\begin{array}{l}\text { Tupa cocau. } \\
\qquad \begin{array}{l}\text { Se dira el sanctissimo } \\
\text { Sacramento al qual le } \\
\text { conuienen mejor estas } \\
\text { propriedades, de tupa cocau } \\
\text { y con verdad. ... }\end{array}\end{array}$ & $\begin{array}{l}\text { Royal travel provision (Q). } \\
\text { This is what the Holy } \\
\text { Sacrament will be called; } \\
\text { these characteristics of tupa } \\
\text { cocau are most suitable for } \\
\text { it, and this is rightly so (S). }\end{array}$ \\
\hline 6 & $\begin{array}{l}\text { Tupa. } \\
\qquad \begin{array}{l}\text { Es nombre de honor para } \\
\text { honrrarse, o llamarse } \\
\text { honrrosamente, como } \\
\text { nosotros dezimos Señor, } \underline{A} \\
\text { tupay o Señor, } \underline{\text { A tupay Dios, }} \\
\text { o Señor Dios, tupay San } \\
\text { Pedro o Señor san Pedro. }\end{array}\end{array}$ & $\begin{array}{l}\text { Royal / noble (Q). } \\
\qquad \begin{array}{l}\text { It is a name of honour for } \\
\text { someone to be honoured, or } \\
\text { be named honourably, as we } \\
\text { say Lord: } \text { A tupay or Lord; A } \\
\text { tupay God, or Lord God; } \\
\underline{\text { tupay Saint Peter, Oh Lord }} \\
\text { Saint Peter (S). }\end{array}\end{array}$ \\
\hline 7 & $\begin{array}{l}\text { Tupa cuca. }{ }^{37} \\
\text { Coca de hoja menuda la mas } \\
\text { sabrosa coca Real. }\end{array}$ & $\begin{array}{l}\text { Royal coca (leaf) (Q). } \\
\text { Coca of tiny leaves, the most } \\
\text { delicious, royal coca (S). }\end{array}$ \\
\hline
\end{tabular}

37 Guaman Poma ([ca. 1615] 2001: 267 [269]) says that the Chinchaysuyus sacrifced, among other things, "tupa coca". 


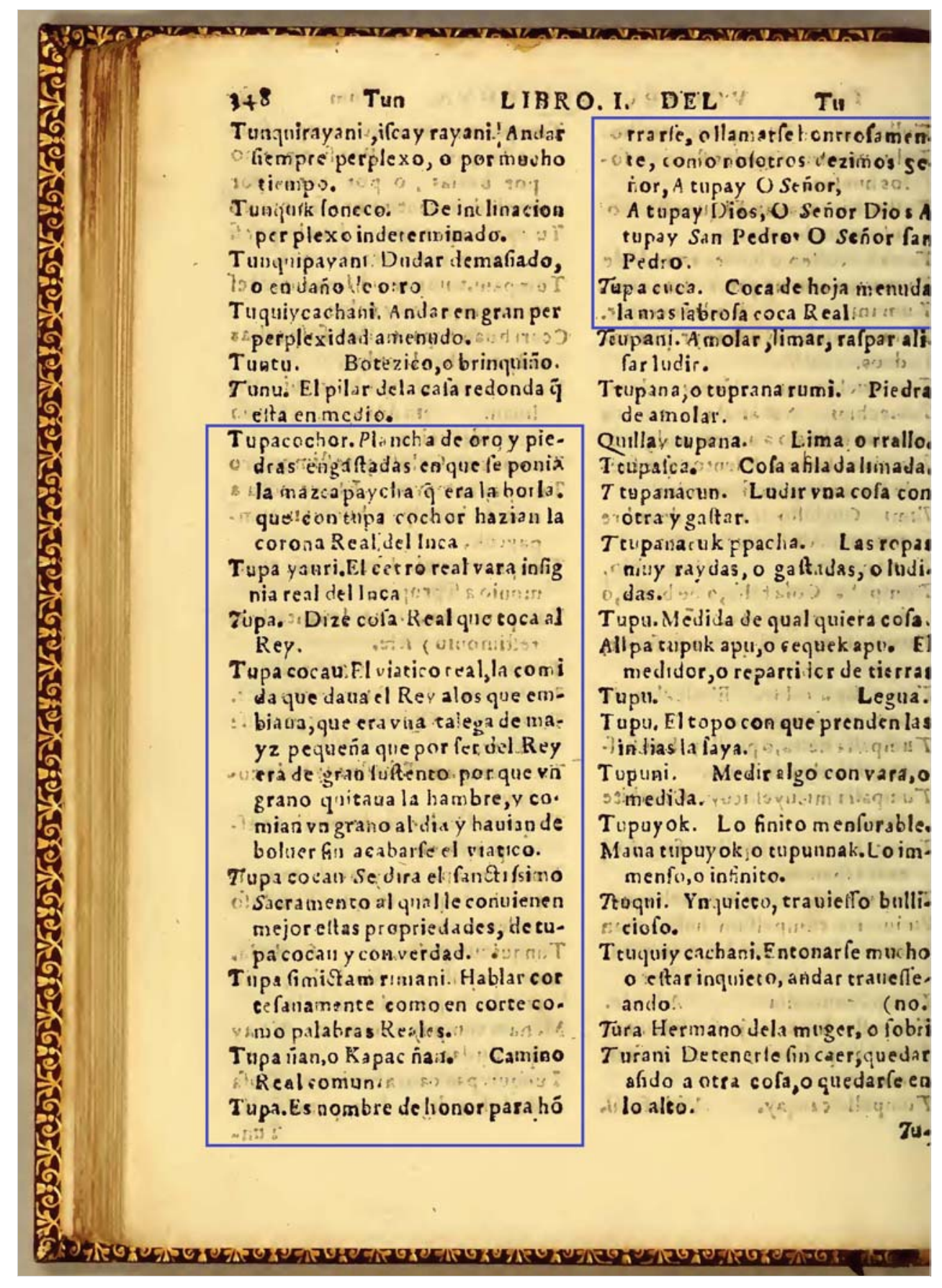

Illustration 1: González Holguín, Vocabulario 1608 (Qu-Sp: 348)

The central word González Holguín uses is tupa, which can be translated as 'noble', 'honourable', 'precious', and was above all used in prehispanic times for persons and objects relating to the Incas themselves. González Holguín recurs to the European concept of 'royal' in his explanations of the term itself (3) and several objects related to the Inca (the Inca's headdress in 1, the Inca's scepter in 2, and the special coca leaf ${ }^{38}$ in

38 The coca leaf (Erythroxylon coca [Allaby ed. 2013: s.v. Erythroxylon]) has a long tradition in the Andes - it is chewed as a stimulant, for stress relief, to reduce the 
7). But by using the adjective 'royal', the concept of Inca nobility is related to Spanish nobility and also to Christian divinity, as a honorific title (6). It is evident here that for González Holguín there is no division between the political and the religious sphere. And thus he constructs a full circle: Spanish royal = Inca royal = divine, and implicitly the Incas can be seen as Christians. ${ }^{39}$

However, the most interesting and explicit relation to the Eucharist is that of the travel provisions given by the Incas to their messengers (4). In trying to explain and find a word for the embodiment of the deity (Christ) in the ingested object (the Host), González Holguín equals it to the extraordinary character and strength the Inca provisions had. And he does so clearly and emphatically, justifying his translation: "se dira ... y con verdad", '[the Holy Sacrament] will be called [tupa quqaw, noble travel provision] ... and this is rightly so'.

But not only did his translation enable the missionaries to understand which Andean word could be used to convey the Christian concept; moreover they could have understood that the Inca object in question was, indeed, related to Christianity because 'viático' means both 'travel provision' and 'Eucharist' ${ }^{40}$ - here the Christian and the Inca meaning almost seem to coincide.

What would the equivalence of the word for an object and concept of Inca culture with a Christian one have done to the Andean mind? Although we do not know in how far the Inca domination was still present in people's memory, we can suppose that they related tupa with concepts which were exclusively reserved for any kind of highly respected noble class. It is therefore understandable that González Holguín chooses this Quechua word, tupa quqaw, for the Holy Communion. Considering, however, the Inca's religious function as son of the Sun, the equivalence of the most important sacrament with the Inca's special food must have invited the integration of the Christian concept into the Andean one. In the worst (or best?!) case, indigenous people would not have known anymore what tupa quqaw was in Inca society and would have (only) been able to understand the Holy Communion as a very special food one would take with oneself on a trip (quqaw).

feeling of hunger; and it is used in healing and divination ceremonies, in offerings and for social purposes (cf. Allen [1988] 2002). As Serna (2006: [14]) points out, the chronicler Inca Garcilaso de la Vega and the Jesuits tried to explain that the indigenous people were inherently Christians (Garcilaso de la Vega 1609, I. II, cap. II: 27).

40 Documented with both meanings in the Diccionario de Autoridades ([1739/VI], 1990/3: 474).

See also in the Catechism of Trent ([1566] 1823, On the Sacrament of the Eucharist: 147): "Sacred writers also frequently call it 'The Viaticum' as well because it is the spiritual food by which we are supported during our mortal pilgrimage". 
González Holguín chooses a linguistic equivalent which he considers to be close in meaning to the concept he wants to translate, and this cultural substitution can have the impact on the indirect target group, the Andean people, that they relate their own concept with the new one. At the same time it can do the same to the immediate target group, the missionary who learns Quechua, i.e. he could relate the Andean concept to his own, Christian one.

As we will see, going even further than equating the miraculous Inca travel provision to the Eucharist, González Holguín directly identifies the baby llama the Incas sacrificed with the Lamb of God.

F The Eucharist is the Inca sacrifice of the baby llama

\begin{tabular}{|l|l|l|}
\hline & $\begin{array}{l}\text { González Holguín } \\
(1608, \text { Qu-Sp: 160; 1989: 166) }\end{array}$ & Translation by SDS \\
\hline $\begin{array}{l}\text { Quechua } \\
\text { Spanish }\end{array}$ & $\begin{array}{c}\text { From Quechua (Q) } \\
\text { From Spanish (S) }\end{array}$ \\
\hline 1 & $\begin{array}{c}\text { Huaccar. } \\
\text { Garça blanca cuelli larga } \\
\text { pocas carnes. ... }\end{array}$ & $\begin{array}{c}\text { Great white egret (Q). } \\
\text { White heron with long neck } \\
\text { and little flesh (S). }\end{array}$ \\
\hline 2 & $\begin{array}{c}\text { Huaccarpaña vña. } \\
\text { Cordero blanco sin mancha } \\
\text { para sacrificios. }\end{array}$ & $\begin{array}{c}\text { White baby llama for sacrifice (Q). } \\
\text { White lamb without spot for } \\
\text { sacrifice (S). }\end{array}$ \\
\hline 3 & $\begin{array}{l}\text { Huaccapaña [sic] vñanchic } \\
\text { checamanta lesuchristom casca. } \\
\text { Nuestro verdadero Cordero y } \\
\text { sacrificio es Jesucristo. }\end{array}$ & $\begin{array}{c}\text { Our white baby llama for sacrifice } \\
\text { is/was really Jesus Christ (Q). } \\
\text { Our real Lamb and sacrifice is } \\
\text { Jesus Christ (S). }\end{array}$ \\
\hline
\end{tabular}

The Great White or American Egret (Ardea alba egretta), called 'garza', 'heron' (1), is a large white bird that lives in wetlands and is native to the Americas. ${ }^{41}$ When one compares it to a white baby llama (2) (see Illustrations 2 and 3), the similarities in their whiteness and long necks are startling enough; moreover in the Andes this water bird is also linked to the mythical origin of the llama which came out of a fountain (DedenbachSalazar Sáenz 1990: 183-184; Mariscotti 1978: 216, 221, 229). Although the etymology of "huaccarpaña" is unknown, it is quite obvious that this part of the word is related to the white bird; uña is a young animal, such as a lamb or baby llama. ${ }^{42}$ Whilst González

\section{$41 \quad$ American Egret (1992-2016).}

42 González Holguín 1608, Qu-Sp: 354, 1989: 355; see also González Holguín 1608, Sp-Qu: 78, 1989: 449: 'White ram without spot which the Indians sacrificed ...' ("Carnero blanco sin mancha que sacrificauan los indios, huacarpaña"). In Aymara, Bertonio ([1612] 1984, Ay-Sp: 141) has "Huaccarpaña; Carnero blanco muy lanudo", 'very woolly white ram', without mentioning its sacrificial aspect (the 
Holguín's translation of the bird is an accurate description of what he must have seen (1), the term "huaccarpaña vña" apparently only referred to the white baby llama as sacrificial animal (2) and was probably elicited from his consultants. We do not know whether this kind of sacrifice was still being made at the beginning of the 17th century, but the chronicler Cieza de León still witnessed it in the 1550 s. ${ }^{43}$ Despite the uncertain etymology the 'sacred' character of this animal moved González Holguín to suggest it as equivalent translation for Agnus Dei.

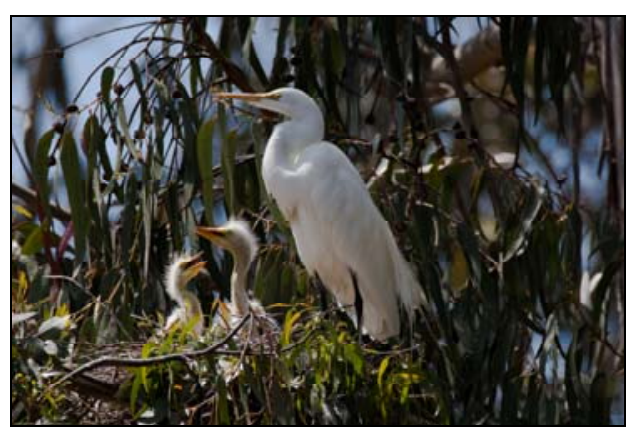

Illustration 2: Great Egret

(Ardea Alba 2009)

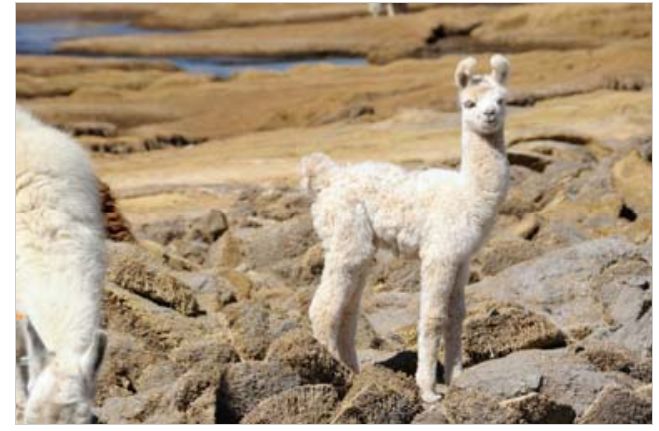

Illustration 3: Baby llama ([2008])

(Courtesy of Tim Wellhausen)

verb "huacca-" means 'to comb the wool by hand', ibid.). It is possible that this is connected to the custom to use (still at present) the fine wool from the llama's neck to weave ceremonial garments (Lindsey Crickmay, personal communication, 17 January 2017). In Quechua paña means 'right hand, right-hand side' (González Holguín 1608, Qu-Sp: 274, 1989: 277), but it is not an Aymara word (Bertonio [1612] 1984, Sp-Ay: 207). In Quechua the additive meaning of the elements as a word-for-word translation ( ${ }^{*}$ white heron - right-hand side) does not make much sense, and it is possible that the word as a whole (and its meaning in religious ritual) is a loan from another language (such as Puquina), possibly adapted through a folk-etymology.

43 He wrote: 'they brought a [llama] lamb up to one year of age without any spot, of one single colour ... stretched out on the ground alive, they removed its entire entrails from one side: and these were given to their diviners whom they called Guacacamayos [specialists in charge of the sacred], like priests among us. And I saw that certain of their Indians took hurriedly in their hands as much of the lamb's blood as they could and spread it among the potatoes they had in the sacks', "traxeron vn cordero de hasta vn año sin ninguna mancha todo de vna color ... tendido en el suelo biuo le sacaron por vn lado todo el assadura: y esta fue dada a sus agoreros, que ellos Ilamauan Guacacamayos, como sacerdotes entre nosotros. Y vi que ciertos indios de ellos lleuauan a priessa quanto más podían de la sangre del cordero en las manos, y la echauan entre las papas que tenían en los costales." (Cieza de León [1553] 1984, cap. CXVII: 306). Cf. Molina, Mayo [ca. 1575] 2010: 47; Polo de Ondegardo cap. VI [1585b: fol. 9v], 1985b: 270. 
In the Western biblical tradition, the white lamb, Agnus Dei, is a common element in the liturgy of the mass, a metaphor for the Eucharist, and as such it has also been widely used in iconography (see Illustrations 4 and 5). ${ }^{44}$

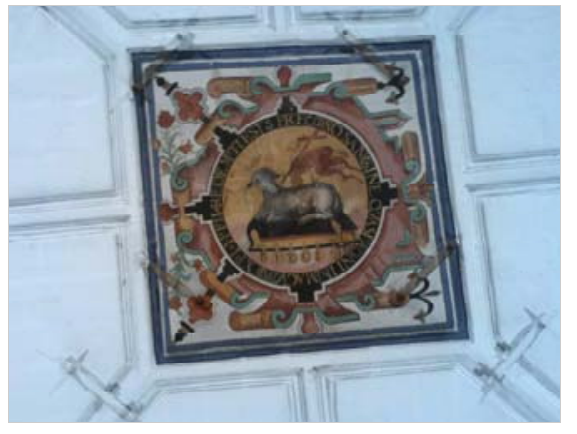

Illustration 4:

Agnus Dei - The Lamb of God on the Book with Seven Seals. Iglesia de la Anunciación, Sevilla, España, $1616^{45}$

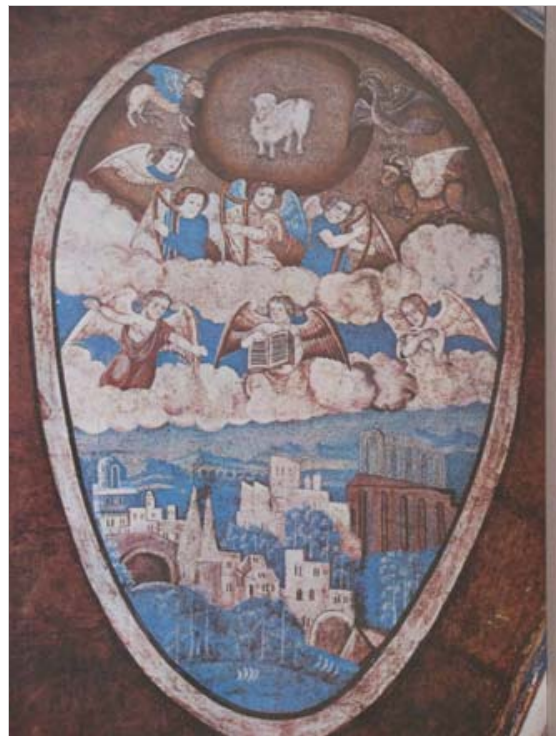

Illustration 5:

The Lamb of God, by Juan Gerson.

Sotocoro, Temple of the Franciscan Ex-

Convent of La Asunción de Nuestra Señora,

Tecamachalco, Puebla, Mexico [1562] 1972

Thus, as the verbally and visually well known concept had to be expressed in Quechua, González Holguín decided to explain the Eucharist through the Andean concept of the sacrificial lamb. In this case, rather than a metaphor, he used the verb 'to be' (ka-) and the Quechua witness evidential (-m/-mi): "Huaccapaña [sic] vñanchic checamanta lesuchristom casca", 'Our white baby llama for sacrifice is/was really Jesus Christ - I have seen it' (3). ${ }^{46}$ In this way he equates the Andean and the Christian concept, and although his Spanish translation seems, as equivalent, to render faithfully the Andean meaning he gives (3), the meaning of the Quechua term evokes a completely different cultural and ritual context from that of the Spanish word, each embedded in and associated with a different faith. The linguistic method he uses in equating "huaccarpaña

$44 \quad$ For example, the Catechism refers to 1 Peter 1: 18-19: “... with the precious blood of Christ, as of a lamb unspotted and undefiled." (Catechism of Trent [1566] 1823, On the fourth article of the Creed: 50 ). Agnus Dei ([1616b] 2016); for a description see Agnus Dei ([1616a] 2012). Statements which in Quechua cannot carry this suffix because they could not possibly be witnessed, received this suffix as a kind of emphatic validator in Christian Quechua (Dedenbach-Salazar Sáenz 1999b: 231-232). 
uña" with "lamb and sacrifice" (see bolding in F3) fuses the Christian and the Andean explicitly.

To highlight the differences between the 'pagan' and Christian sacrifice, the authors of the sermon written by the Third Lima Council in the Tercereo Cathecismo had noted that 'we do not offer a llama, a young animal', in Quechua: "manam llamactachu, manam vñactachu cocunchic" (sermon XIII [1585: fol. 73v]; 1985: 494) ${ }^{47}$, but by negating the Andean ritual, they still evoked the comparison. González Holguín's contextualisation of the Holy Communion in the Andean sacrifice is also more explicit compared to the Doctrina Christiana where the word quku-, 'to offer' (cf. Dedenbach-Salazar Sáenz 2013: 232) is used to describe that Jesus Christ is the ultimate scarifice (Doctrina Christiana [1584: fol. 49r]; 1985: 117). However, the Doctrina answer to what there is after the consecration of the sacrament states that it consists of the 'real body and blood of Jesus Christ', "el verdadero cuerpo y sangre de lesu Christo", quite literally translated into Quechua as "lesu Christo apunchicpa checan vcun, checan yahuarinmi” (ibid. [fol. 48v]; p. 116,), 'the real body, the real blood of our lord Jesus Christ', which is, of course, not far from a possible Andean understanding of sacrifice.

Thus, almost a quarter of a century later González Holguín, a Jesuit like Acosta who was responsible for the Doctrina Christiana (Dedenbach-Salazar Sáenz 2013: 5051), explicitly refers to Inca sacrifices in order to explain the Agnus Dei. And although the Incaic sacrifice was supposed to be exterminated with the colonisation, people must have remembered it, and the fact that it was still carried out at least in the 1970s shows its vitality and continuity (Nachtigall 1975).

47 In the letter to the Corinthians (1, 10: 14-21) it is made clear that the Communion has to be differentiated from the pagan sacrifice (New Jerusalem Bible 2015, http://www.catholic.org/bible/book.php?id=53\&bible chapter=10; Biblia Sacra Vulgatae 1592: 1010; cf. 1 Peter 1: 18-19, at http://www.catholic.org/bible/book.php?id=67; Biblia Sacra Vulgatae 1592: 1064). However, Christ's quoted exhortation to 'eat, this is my body', "micuychic caymi ñocap vcuy" (Tercero Cathecismo [1585: fol. 74v], 1985: 496), may have had resonances of the entrails of an animal which was used for divination and which was then eaten. 


\begin{tabular}{|c|c|c|}
\hline & $\begin{array}{l}\text { González Holguín } \\
\text { (1608, Qu-Sp: 285; 1989: 166) }\end{array}$ & Translation by SDS \\
\hline & $\begin{array}{l}\text { Quechua } \\
\text { Spanish }\end{array}$ & $\begin{array}{l}\text { From Quechua (Q) } \\
\qquad \text { From Spanish (S) }\end{array}$ \\
\hline 1 & $\begin{array}{l}\text { Pirani. } \\
\begin{array}{l}\text { Era vna cerimonia que del } \\
\text { carnero, o cordero que auian } \\
\text { de sacrificar con la sangre } \\
\text { nueua y fresca se embijauan } \\
\text { con rayas en la cara, o cuerpo } \\
\text { para tener parte en aquel } \\
\text { sacrificio. }\end{array}\end{array}$ & $\begin{array}{l}\text { I ritually paint [someone] with } \\
\text { blood (Q). } \\
\text { It was a ceremony in which } \\
\text { they painted in their faces or } \\
\text { on their body lines with the } \\
\text { new and fresh blood of the } \\
\text { ram or lamb they had to } \\
\text { sacrifice so that they could } \\
\text { participate in that part of the } \\
\text { sacrifice }(S) \text {. }\end{array}$ \\
\hline 2 & $\begin{array}{l}\text { Pirascca. } \\
\qquad \begin{array}{l}\text { Los embijados, o sulcados con } \\
\text { sangre, y se puede aplicar a } \\
\text { nuestro cordero Christo. }\end{array}\end{array}$ & $\begin{array}{l}\text { Ritually painted with blood (Q). } \\
\text { Those painted, or those with } \\
\text { lines made of blood, and it } \\
\text { can be applied to our Lamb of } \\
\text { God (S). }\end{array}$ \\
\hline
\end{tabular}

Here González Holguín creates yet another cultural equivalent: the blood of a sacrificed animal used to paint one's body in Inca times (1) is, according to him, like the Lamb of God (2). There are numerous passages in the Bible which refer to the blood of Jesus. An interesting one, which links the Old and the New Testament and thereby gives us an idea of some of the similarities Andean and Old Testament religion showed, is the following:

But now Christ has come, as the high priest of all the blessings which were to come. He has passed through the greater, the more perfect tent, not made by human hands, that is, not of this created order; and he has entered the sanctuary once and for all, taking with him not the blood of goats and bull calves, but his own blood, having won an eternal redemption. The blood of goats and bulls and the ashes of a heifer, sprinkled on those who have incurred defilement, may restore their bodily purity. How much more will the blood of Christ, who offered himself, blameless as he was, to God through the eternal Spirit, purify our conscience from dead actions so that we can worship the living God. ${ }^{48}$

These verses indicate the salvation of humankind through the offering of Christ's blood in the Eucharist ceremony, and González Holguín makes the transference of the word for

$48 \quad$ New Jerusalem Bible 2015, Hebrews 9: 11-14, at http://www.catholic.org/bible/book.php?bible chapter=9\&id=65. Cf. Biblia Sacra Vulgatae 1592, p. 1055. For further passages see the King James Bible 2007, https://www.kingjamesbibleonline.org/bible-verses-about-the-blood-of-jesus/. 
painting oneself with sacrificial animal blood to the Lamb of God completely explicit: "it can be applied" (2) - like the Inca travel provision as Holy Communion (E4). Again, he suggests more than the translation and application of an everyday word to a Christian concept: he makes an equation of Inca and Christian rites possible and thinks that it is acceptable. $^{49}$

\section{Extreme Unction}

In the 17th centrury the sacrament of the Extreme Unction was given to those who where about to die. The anointment of the sick or dying person served to prepare him for the meeting with God. It is therefore an important Christian ritual, and this is reflected in the fact that the 1585 Tercero Cathecismo dedicated a whole sermon (17) to it (after a very brief treatment in the Catecismo Mayor of the Doctrina Christiana [1584: fol. 52v-53r]; 1985: 124-125). According to the authors it has three objectives: the pardon of all sins, to cure the body of its illness, and the strength to gain the coming battle with the Devil (ibid. [fol. 95r-96r], pp. 537-539).

\section{H Extreme Unction and ritual ointment}

\begin{tabular}{|c|c|c|}
\hline & $\begin{array}{l}\text { González Holguín (1608, Qu-Sp: } \\
215 \text {, cf. 149; 1989: 166) }\end{array}$ & Translation by SDS \\
\hline & $\begin{array}{l}\text { Quechua } \\
\text { Spanish in Quechua text in italics } \\
\text { Spanish }\end{array}$ & From Spanish (S) \\
\hline 1 & $\begin{array}{l}\text { Llussini o hauini. } \\
\qquad \text { Vntar, o vngir. }^{50} \ldots\end{array}$ & $\begin{array}{l}\text { I anoint or I spread a greasy } \\
\text { substance (Q). } \\
\text { To apply an oily substance } \\
\text { (S). }\end{array}$ \\
\hline 2 & $\begin{array}{l}\text { Llussina hanpi. } \\
\qquad \text { V[n]guentos o vnciones. }\end{array}$ & $\begin{array}{l}\text { Herbal medicine to be applied as } \\
\text { ointment (Q). } \\
\text { Oily substances to be } \\
\text { applied (S). }\end{array}$ \\
\hline 3 & $\begin{array}{l}\text { Llucsina [sic] sacramento. } \\
\qquad \begin{array}{l}\text { El sacramento de la } \\
\text { extrema vncion. }{ }^{51}\end{array}\end{array}$ & $\begin{array}{l}\text { The Sacrament to be applied as } \\
\text { ointment (Q). } \\
\text { The sacrament of the } \\
\text { Extreme Unction (S). }\end{array}$ \\
\hline
\end{tabular}

49 Durston (2007: 278-279) mentions two colonial hymns in which Christ is described as being inside the Host - yet another explanation which may have led to misunderstandings.

$50 \quad$ Diccionario de Autoridades [1739/VI] 1990/4: 388, 394. 


\begin{tabular}{|l|l|l|}
\hline 4 & $\begin{array}{c}\text { Extremauncionhuan llussiy tucuni. } \\
\text { Ser vngido. }\end{array}$ & $\begin{array}{l}\text { I am rubbed in with the Extreme } \\
\text { Unction (Q). } \\
\text { To be anointed (S). }\end{array}$ \\
\hline 5 & $\begin{array}{c}\text { Sacramentohuan llussini. } \\
\text { Vngir o dar la extrema } \\
\text { vncion. }\end{array}$ & $\begin{array}{c}\text { I rub on the Sacrament (Q). } \\
\text { To anoint or give the } \\
\text { Extreme Unction (S). }\end{array}$ \\
\hline 6 & $\begin{array}{c}\text { Sacramentohuan llussisca. } \\
\text { El vngido. }\end{array}$ & $\begin{array}{l}\text { The one who is rubbed in with the } \\
\text { Sacrament (Q). }\end{array}$ \\
\hline 7 & $\begin{array}{l}\text { Vya llussina. } \\
\text { Tos afeytes, }\end{array}$ & $\begin{array}{l}\text { The substance to rub on the face } \\
\text { (Q). }\end{array}$ \\
\hline 8 & $\begin{array}{l}\text { oyacta llussicuni. } \\
\text { Embellishments (S). }\end{array}$ \\
\hline
\end{tabular}

In this context, González Holguín uses the Quechua terms for 'to rub a substance on the body' (Spanish 'untar'), i.e. hawi- or Ilusi-. ${ }^{52}$

In a Quechua speaker, the usage of the Quechua words would at least have evoked the action itself. Therefore it seems to be an adequate choice to use llusi- in combination with the Spanish word, either 'sacrament' or 'Extreme Unction' (again, as loanwords), but it would only have evoked the physical aspect of rubbing a substance on the skin, not necessarily that of the ritual aspect for which González Holguín only uses loanwords.

$51 \quad$ From here onwards all the entries I have separated form one entry in González Holguín.

52 Hawi- and llusi- clearly refer to painting things or the face (González Holguín 1608, Qu-Sp [149], 1989 155-156; and 1608, Sp-Qu: 314, 1989: 686-687 resp., cf. Lira 1944: 236, 602). Of course, we do not know whether there was any kind of facial painting for embellishment only, without further ritual meaning, and González Holguín does not clarify this.

Santo Tomás has a number of words, of which hawi- means 'to paint oneself with any kind of colour in general' ([1560: fol. 6r] 1951: 18; fol. 137v, p. 292), and the same word also means that the woman paints herself with black oil (ibid. fol. $6 r, p$. 28) - this explains why hawi- is used in the sermon for the Extreme Unction: "he applies Holy Oil', "sancto oliohuan hauin" (Tercero Cathecismo sermon XVIII [1585: fol. 95r], 1985: 537). 
Similarly he used pira-, which refers to the painting of the face or body with fresh llama blood in a particular sacrifice ritual, to express the Lamb of God (G2). Several Spanish colonial sources describe the ritual anointment of adored people, objects or animals. Augustinian monks saw a ritual in Central Peru where, apparently in order to guarantee the fertility of maize, guinea pig blood was sprinkled on maize leaves. The rocks of a huaca (deity, sacred object) were rubbed with the blood of sacrificed guinea pigs; another huaca in the form of a stone was painted with the red colour of a certain tree. ${ }^{53}$ Polo de Ondegardo mentions how sorcerers healed the sick by rubbing on their body the ointment of a guinea pig or frog's fat or meat, or plants such as maize, hoping for them to be healed. Other occasions where ointments were used were festivals, and Ondegardo also reminds us that the dead Incas' bodies were embalmed and their faces painted with the blood of children who were sacrificed on these occasions. ${ }^{54}$ We can see that the ritual process of applying certain substances to the body was well known in Andean culture. This would have made it relatively easy to transfer the indigenous understanding to a Christian ritual, facilitating once again a fusion of both, and it is obvious from the examples that González Holguín used these interpretations intentionally.

\section{Conclusion}

By combining in his translations word-for-word equivalents, extensions of meaning and loanwords with Andean everyday and ritual terms, González Holguín created what one might call neologisms. But these are not lexical neologisms; rather, they are cultural parallels created through metaphors and the explicit equation of Christian and Andean beliefs. Andean words are used in these sentences, completely embedded in and surrounded by their own context so as to draw Christian terms and concepts into the Andean world. The purpose was obviously to integrate Andean elements into Christian faith more easily, but it also would have established parallels between both religions, which enabled Andean people to see their own rites as equal to Christian ones - a

53 “... y allí las [flores del maíz] mochan y sacrifican un coy y a las hojas mesmas echándoles la sangre encima" (Agustinos [1560/61: fol. 15v], 1992: 41); cf. "y ofresçíale coyes y untavan las peñas con la sangre" (ibid. fol. 7v, p. 22); "estava esta piedra e ydolo / muy enbixado, ques un colorado que allá tienen muy preçiado a manera de bermellón" (ibid. fol. 8r, p. 23).

"Los enfermos se suelen embadurnar el cuerpo con mayz, o con otras cosas, o embadurnar a otros para sanar de sus enfermedades" (Polo de Ondegardo, cap. V, no. 11 [1585a, fol. 4v], 1985a: 260); “... vntandoles con sebo, o con carne, o grossura del Cuy, o Sapo, o de otras immundicias, o con yeruas" (Polo de Ondegardo, cap. IIII [1585a, fol. 5r], 1985a: 257); cf. Polo de Ondegardo, cap. II, no. 12 [1585b: fol. 8r], 1985b: 267; cap. XIV [1585b: fol.15v], 1985b: 282.

From a varied semantic field in the dictionaries and these Spanish sources one can conclude that the application of body colours and other ointments was important in Andean culture and that applying them was also a means of healing. 
cultural substitution which worked both ways. Probably through its lack of orthodoxy this kind of cultural transference and convergence did not survive the colonial period, although it did reflect common practice of the time. Thus Polo de Ondegardo (cap. XIV [1585b, fol.15r-v]; 1985b: 282) had mentioned that the two systems were in use:

indigenous 'sorcerers' employed Christian phrases and gestures and at the same time continued applying their own rituals; that is, only fifty years after the conquest the Andean people seemed to have learned to combine both types of rituals which superficially did probably not seem to be very different from each other to them.

On the linguistic level, what initially was a translation/transference of Christian metaphors into Quechua became a re-interpretation of Christian forms within the Andean cultural framework. Whereas the other colonial missionaries chose loanwords or literal translations, González Holguín is the only author (ancient and modern) who recontextualised Christian and Andean terms and concepts by translating the key terms into Quechua and creating metaphors ${ }^{55}$ based on the Andean culture, and thus, in a way, making it possible to bring two different visions of the world together through textual images.

Thus we can see in three cases, "tupac cocau", "huaccarpaña vña" and "pirascca", how González Holguín used the Andean words, fraught with cultural and religious meanings of the Inca era, to integrate the most central meaning of Christianity, that of the Eucharist, into the Andean world - and not the other way round! Linguistically he made his choice clear by assigning the Christian meanings explicitly to the Andean words by using 'is', 'will be called' and 'can be applied', and by integrating them into Quechua sentences. It is therefore clear that González Holguín took a conscious decision rather than making an intuitive translation. ${ }^{56}$

This finds its support in González Holguín's recontextualisation of Quechua words and concepts through his supposedly Christian interpretation and it makes the fusion process practically an orthodox one. It means that, at least in these examples, González Holguín explicitly creates Christian Quechua concepts which aim at combining or amalgamating Andean and Christian beliefs. However, whilst rituals themselves which combined elements from both beliefs, have persisted through the centuries (e.g. Marzal 1992; Albó 1999), González Holguín's unorthodox translations did not become part of Quechua Christian discourse. ${ }^{57}$ There is no documentation as to why this was the case,

55 It would be interesting to study if and how the sermons written by 17 th century priests make use of methaphors.

56 In their religious texts, other missionaries used the Spanish loanwords for Host (Doctrina Christiana, Catecismo Mayor, de los sacramentos [1584: fol. 46r], 1985: 111 ) as do contemporary hymns (Durston 2010: 151).

$57 \quad 20$ th century massbooks use the loanwords introduced by the Third Lima Council in the 1580s, e.g. the Eucharist is the 'unique sacrifice', "Sacrificio singular", translated into Quechua as 'principal sacrifice', "sacrificio collanam" (Doctrina cristiana en quechua [between 1958 and 1963]: 52); similarly 'Holy Communion', "Santa Comunion" in Quechua, and 'Most Holy Sacrament of the Altar', "Santísimo Sacramento Altarpi" (ibid. 54). Equally in (Protestant) Bible translations Agnus Dei 
for example critical Church comments as to an unorthodox usage of language. On the contrary, the dictionary was approved by the Real Audiencia and by the Church because - so wrote the Jesuit Juan Vázquez in his Aprobacion in 1607 - it has

examined and inquired particularly well the words and their use and easy acommodation to ours, and of their phrases and ours, everything so appropriately that I hope that it will be of much help for the priests and those who would like to use [it] in the preaching of the Holy Gospel in order to promote faith and good customs. This is because this work has a very large amount of terms and words which have now been adapted to the spiritual in order to declare the mysteries of our holy faith, vices and virtues which the language lacked. ${ }^{58}$

Rather than having difficulties because of his unorthodox translations which contributed to amalgamating the religions, probably few parish priests used the dictionary because they may generally have relied on the Quechua Christian Doctrine of the Third Lima Council and lacked the time and interest to verify the translation of certain key terms in a comprehensive book which - moreover - does not seem to have been easily available.

The difference in the translation of key Christian concepts in the Third Lima Council texts, directed by the Jesuit José de Acosta, and that of González Holguín, Jesuit as well, also shows that there does not seem to have been a clear strategy adopted by a certain religious order.

With respect to the impact González Holguín's work might have had, there is no evidence documented in writing that it influenced the development of what is now called 'Andean religion', but it does seem probable that the fusion we see here may have been supported orally by his indigenous consultants who represented the contact the two religions had from early on. Thus, in a way González Holguín's translations reflect the practice of the indigenous people of amalgamating European and Andean culture, which began almost as soon as the Christianisation.

is translated using a loanword (John 1: 29), e.g. 'God's lamb', "Diospa Corderon" (Señorninchis Jesucristoq Mosoq Rimanakuynin 1966: 297), or 'God' combined with the Quechua word for 'young animal': “Diospa Chitanta” (Senorninchik Jesucristopa Musuq Testamenton, John 1: 29, 1958: 261).

We do not know if González Holguín's terminology was not accepted because it was not considered orthodox or simply because the discourse used in early doctrinal materials was easier to continue to employ than the words presented in a dictionary (re-edited for the first time only in 1842 [Hamerly 2011: 46]), which would have needed some analytic effort.

Translation SDS; "particular examen y aueriguacion de la propiedad de los vocablos, y el vso y acomodacion facil de ellos a los nuestros, y de sus frases y nuestras, todo con tanta propriedad que espero ha de ser de mucha ayuda a los Curas y a los que se quisieren emplear en la predicacion del santo Evangelio para el aumento de la fee y buenas costumbres por tener esta obra grandissima copia de terminos y vocablos nueuamente acommodados a lo espiritual para la declaracion de los mysterios de nuestra sancta fee, vicios, y virtudes de que tenia falta la lengua". 


\section{References}

\section{Agnus Dei}

2012 Patrimonio histórico-artístico. Universidad de Sevilla [1616a]. <

http://www.patrimonioartistico.us.es/objeto.jsp?id=1630\&tipo=v > (accessed 04.02.2019).

2016 El Cordero de Dios sobre el Libro de los Siete Sellos [1616b]. Iglesia de la Anunciación, Sevilla, Andalucía, España. Photo: CarlosVdeHabsburgo, 2016. < https://commons.wikimedia.org/wiki/File:Cordero y libro.jpg > (accessed 04.02.2019).

\section{Agustinos}

1992

Relación de la religión y ritos del Perú hecha por los padres agustinos [1560/61]. Edición, estudio preliminar y notas de Lucila Castro de Trelles. Lima: Pontificia Universidad Católica del Perú, Fondo Editorial. (Clásicos Peruanos.)

\section{Albó, Xavier}

1999 Entrecruzamientos lingüísticos en los rituales qullas. In: Sabine Dedenbach-Salazar Sáenz and Lindsey Crickmay (eds.), La lengua de la cristianización en Latinoamérica: Catequización e instrucción en lenguas amerindias / The Language of Christianisation in Latin America: Catechisation and Instruction in Amerindian Languages; 249-276. Markt Schwaben: Verlag Anton Saurwein. (Bonner Amerikanistische Studien / Estudios Americanistas de Bonn / Bonn Americanist Studies - BAS 32; Centre for Indigenous American Studies and Exchange, St. Andrews CIASE Occasional Papers 29).

Allaby, Michael (ed.)

2013 A Dictionary of Plant Sciences. Oxford University Press. (Concise Oxford Dictionary of Botany.) Electronic resource 2013 (print edition 2012). < http://www.oxfordreference.com/view/10.1093/acref/9780199600571.001.0 $\underline{001 / a c r e f-9780199600571}>$ (accessed 04.02.2019).

\section{Allen, Catherine $\mathrm{J}$.}

2002 The Hold Life Has. Coca and Cultural Identity in an Andean Community [1988]. Washington and New York: Smithsonian Institution. Second edition.

\section{American Egret}

$1992-2016<$ http://avibase.bsc-eoc.org/species.jsp?avibaseid=08BBEBEFCF985782 >. In: Avibase - The World Bird Database, author Denis Lepage, hosted by Bird Studies Canada, < http://avibase.bsc-eoc.org/avibase.jsp?lang=EN >. (Both accessed 04.02.2019.) 


\section{Anonymous}

1586 Arte, y vocabulario en la lengua general del Peru llamada Quichua, y en la lengua española. Los Reyes [Lima]: Antonio Ricardo. < https://archive.org/details/arteyvocabulario00unkn > [John Carter Brown Library copy (title pages missing)] (accessed 04.02.2019).

\section{Araníbar, Carlos}

1995

Índice analítico y glosario. In: Juan de Santacruz Pachacuti Yamqui, Relación de las antigüedades des este reino del Perú. Edición, índice analítico y glosario de Carlos Araníbar; 135-427. México D.F.: Fondo de Cultura Económica. (Sección de Obras de Historia.)

Ardea Alba

$2009<$ https://en.wikipedia.org/wiki/Great egret\#/media/File:Ardea alba chicks and nest -Morro Bay Heron Rookery -8.jpg > (accessed 04.02.2019).

Ayrosa, Plínio (ed.)

1938 Vocabulário na língua brasílica. Manuscrito português-tupi do século XVII [1622]. São Paulo: Departamento de Cultura. < http://www.etnolinguistica.org/biblio:anonimo-1938-vocabulario $>;<$ http://etnolinguistica.wdfiles.com/local--files/biblio\%3Aanonimo-1938vocabulario/anonimo 1938 vocabulario.pdf > (accessed 04.02.2019).

Baby Ilama

[2008] < http://www.tim-wellhausen.de/graphics/pictures/Bolivien/slides/Bolivien0389.html > (accessed 04.02.2019).

Baker, Mona

1992 In Other Words: A Coursebok on Translation. London: Routledge.

\section{Bertonio, Ludovico}

1984 Vocabulario de la lengua aymara [1612]. [Facsimile.] Cochabamba: Centro de Estudios de la Realidad Económica y Social. [Also: < https://openlibrary.org/works/OL15368340W/Vocabulario de la lengua ay mara. Primera parte > or:

https://ia600503.us.archive.org/27/items/vocabulariodelal00bert/vocabulario delal00bert.pdf $>$ (accessed 04.02.2019).

Bible

see Biblia Sacra Vulgatae 1592

King James Bible Online 2017

New Jerusalem Bible 2015

In this paper I refer to the English editions for easier understanding. There was no Spanish translation of the Bible recognised by the Catholic Church 
before the end of the 18th century when Felipe Scío de San Miguel's translation was published as the first authorised Catholic Bible (WorldCat 2001-19: < https://www.worldcat.org/title/biblia-vulgata-

latina/oclc/630645937\&referer=brief results); the Spanish Reina Valera Bible was written by Protestants, published in 1602 (WorldCat 2001-19: < https://www.worldcat.org/title/biblia-que-es-los-sacros-libros-del-vieio-ynvevo-testamento-revista-y-conferida-con-los-textos-hebreos-y-griegos-ycon-diversas-translaciones/oclc/8791018\&referer=brief results $>$ ) (both accessed 04.02.2019). Therefore González Holguín would have read the Latin Vulgata, probably the edition made in 1592 (Biblia Sacra Vulgatae).

\section{Biblia Sacra Vulgatae}

1592

Editionis Sixti V. Pont[ificis] max[imi] iussu recognita atque [et Clementis VIII autoritate] edita. Roma: Typographia Apostolica Vaticana. < https://archive.org/details/bub gb 3C2L2PRq5JIC > (accessed 04.02.2019).

Braak, Ivo

1969 Poetik in Stichworten. Literaturwissenschafltiche Grundbegriffe. Eine Einführung. Kiel: Ferdinand Hirt. 3rd extended and updated edition. (Hirts Stichwörterbücher.)

Catechism $^{59}$

see Catechism of the Catholic Church 2003

Catechism of Trent [1566] 1823

Catechismvs ex decreto Concilii Tridentini, ad parochos 1572

\section{Catechism of the Catholic Church}

2003 Rome: Libreria Editrice Vaticana. <

http://www.vatican.va/archive/ENG0015/ INDEX.HTM $>$ and < http://www.vatican.va/archive/ENG0015/ FA.HTM $>$ or $<$

http://www.vatican.va/archive/ccc css/archive/catechism/index/s.htm $>$ (all accessed 04.02.2019).

\section{Catechism of Trent}

1823 The Catechism of the Council of Trent [1566], published by command of Pope Pius the Fifth. Translated into English by J. Donovan ..., Maynooth. Baltimore: Lucas Brothers. <

59 González Holguín would have used a Latin edition of the Catechism of Trent (different Latin editions were not exactly identical, and according to the translation of the English version I have used, this one seems to be based on the first Latin version from 1566 [Donovan in Catechism of Trent 1823: 10.) It should be added that there was no translation into Spanish until 1777 (except for the one into Náhuatl and Spanish in Mexico in 1723) (Rodríguez 1998: 14-15). 
https://ia802306.us.archive.org/21/items/thecatechismofth00donouoft/t hecatechismofth00donouoft.pdf > (accessed 04.02.2019).

\section{Catechismvs ex decreto Concilii Tridentini, ad parochos}

1572 Ante qvidem PII V. Pont. Max. iussu conscriptus, ... mandato \& authoritate Reuerendiss. ... Dn. loannis ex Comitibus de Hoya, Episcopi Monasteriensis ... editus. Colonia: Calenius et Quentel. < https://www.deutsche-digitalebibliothek.de/item/L36U7E2KEGRCSEFTLHQIBURSHYPXKEGK > (accessed 04.02.2019).

\section{Cieza de León, Pedro de}

1984 Crónica del Perú. Primera Parte [= Crónica] [Sevilla 1553]. Introducción de Franklin Pease G.Y.; nota de Miguel Maticorena E. (Colección Clásicos Peruanos.) Lima: Academia Nacional de la Historia y Pontificia Universidad Católica, Fondo Editorial. [Also: < http://www.memoriachilena.cl/602/w3article-8649.html > (accessed 04.02.2019).]

\section{D'Altroy, Terence N.}

2015 The Incas. Chichester, West Sussex: Wiley-Blackwell. (Second edition, electronic resource.) (The Peoples of America.)

\section{Dedenbach-Salazar Sáenz, Sabine}

1990 Inka pachaq llamanpa willaynin - Uso y crianza de los camélidos en la época incaica. Estudio lingüístico y etnohistórico basado en las fuentes lexicográficas y textuales del primer siglo después de la conquista. (Bonner Amerikanistische Studien / Estudios Americanistas de Bonn 16.) Bonn. [Also: < http://www.dedenbachsalazar.stir.ac.uk/files/2013/10/DedenbachLos-camelidos-en-la-epoca-incaica.pdf $>$ (accessed 04.02.2019). $]^{60}$

1999a El desarrollo del sufijo -sqa a la luz de las fuentes quechuas del siglo XVIII. Unpublished manuscript.

1999b '... luego no puedes negar que ay Dios Creador del mundo, pues tus Incas con no ser Christianos lo alcanzaron a sauer, y lo llamaron Pachacamac' La lengua de la cristianización en los Sermones de Nuestra Santa Fe de Fernando de Avendaño (1649)." In: Sabine Dedenbach-Salazar Sáenz and Lindsey Crickmay (eds.), La lengua de la cristianización en Latinoamérica: Catequización e instrucción en lenguas amerindias / The Language of Christianisation in Latin America: Catechisation and Instruction in Amerindian Languages; 223-248. Markt Schwaben: Verlag Anton Saurwein. (Bonner Amerikanistische Studien / Estudios Americanistas de Bonn / Bonn 
Americanist Studies BAS 32; Centre for Indigenous American Studies and Exchange, St. Andrews, CIASE Occasional Papers 29).

2008

Dictionaries, Vocabularies, and Grammars in Andean Indigenous Languages. In: Joanne Pillsbury (ed.), Guide to Documentary Sources for Andean Studies, 1530-1900; vol. I, 235-264. National Gallery of Art. Norman, Oklahoma: University of Oklahoma Press.

2013 Entrelazando dos mundos: Experimentos y experiencias con el quechua cristiano en el Perú colonial. Quito: Abya-yala.

2016

Introducción. In: Sabine Dedenbach-Salazar Sáenz (ed.), La transmisión de conceptos cristianos a las lenguas amerindias: Estudios sobre textos y contextos de la época colonial; 1-17. Sankt Augustin: Academia Verlag 2016. (Collectanea Instituti Anthropos 48.) [Also: < http://hdl.handle.net/1893/22965 > (accessed 04.02.2019).]

2017 Deities and Spirits in Andean Belief - Towards a Systematisation. Anthropos 112/2: 443-453.

\section{Diccionario de Autoridades}

1990 Diccionario de la lengua castellana ... por la Real Academia Española. [Madrid: Herederos de Francisco de Hierro, tomo I, 1726; II, 1729; III, 1732; IV, 1734; V, 1737; VI, 1739]. Facsimile, 3 vols. Madrid: Gredos. (Biblioteca Románica Hispánica 5, Diccionarios 3.) [Also: < http://web.frl.es/DA.html > (accessed 04.02.2019).]

\section{Doctrina Christiana}

1985 Doctrina christiana y catecismo para instrvccion de los indios ... [1584]. In: Tercer Concilio Provincial de Lima (ed.) 1985; 5-188. [Also: < https://openlibrary.org/books/OL24440872M/Doctrina christiana y catecis mo para instruccion de los indios $y$ de las de mas personas que ha n de $\mathrm{s}>$ or: $<$ https://www.archive.org/stream/doctrinachristia00cath?ref=ol\#page/n3/mod e/2up > (accessed 04.02.2019).]

\section{Doctrina cristiana en quechua}

[between 1958 and 1963] Misa completa; oraciones, cantos, letanías y responsos. [Lima:] Editorial Mercurio.

\section{Durston, Alan}

2007 Pastoral Quechua. The History of Christian Translation in Colonial Peru, 1550-1650. Notre Dame, Indiana: University of Notre Dame. (History, Languages and Cultures of the Spanish and Portuguese Worlds.) 
Fawcett, Peter

1997 Translation and Language. Linguistic Theories Explained. Manchester: St. Jerome Publishing. (Translation Theories Explained 3.) < https://archive.org/details/PeterD.FawcettTranslationAndLanguageLinguisti cTheoriesExplainedTranslationTheoriesExplained > (accessed 04.02.2019).

\section{Fernández Juárez, Gerardo}

1997 Entre la repugnancia y la seducción. Ofrendas complejas en los Andes del Sur. Centro de Estudios Regionales Andinos "Bartolomé de Las Casas". (Archivos de Historia Andina 24.)

\section{Garcilaso de la Vega, Inca}

1609 Primera parte de los comentarios reales. Lisboa: Pedro Crasbeeck. < http://www.memoriachilena.cl/archivos2/pdfs/MC0014755.pdf $>$ (accessed 04.02.2019).

\section{Gareis, Iris}

1987

Religiöse Spezialisten des zentralen Andengebietes zur Zeit der Inka und während der spanischen Kolonialzeit. Hohenschäftlarn: Klaus Renner Verlag. (Münchner Beiträge zur Amerikanistik 19).

\section{González Holguín, Diego}

1975 Gramatica y arte nveva de la lengva general de todo el Peru, llamada lengua qquichua, o lengua del Inca. [Ciudad de los Reyes (Lima) 1607]. [Reimpresión Vaduz - Georgetown.] [Also: < https://archive.org/details/gramaticayartenu00gonz $>$ and $<$ https://ia801308.us.archive.org/1/items/gramaticayartenu00gonz/gramatica yartenu00gonz.pdf > (both accessed 04.02.2019).]

1608 Vocabvlario de la lengva general de todo el Perv llamada lengua qquichua o del Inca. Ciudad de los Reyes [Lima]: Francisco del Canto. < https://archive.org/details/vocabulariodelal01gonz $>$ or $<$ https://ia600809.us.archive.org/5/items/vocabulariodelal01gonz/vocabulario delal01gonz.pdf $>$ (both accessed 04.02.2019).

1989 Vocabvlario de la lengva general de todo el Perv llamada lengua qquichua o del Inca [Ciudad de los Reyes (Lima) 1608]. Prólogo Raúl Porras Barrenechea. Presentación Ramiro Matos Mendieta. Lima: Universidad Nacional Mayor de San Marcos. [Facsimile of the 1952 edition, includes Addenda.]

I have used the 1989 edition and verified (and corrected where necessary) all the quotations according to the 1608 edition. 
Gow, Rosalind, and Bernabé Condori (eds.)

1976 Kay Pacha. Tradición oral andina. Cuzco: Centro de Estudios Rurales Andinos "Bartolomé de Las Casas". (Biblioteca de la Tradición Oral Andina 1.)

\section{Guaman Poma de Ayala, Felipe}

2001 El primer nueva corónica y buen gobierno (1615/1616) [ca. 1615].

(København, Det Kongelige Bibliotek, GKS $22324^{\circ}$ ). Electronic edition, directed by Rolena Adorno and Ivan Boserup. Facsimile of the manuscript, transcription with annotations, documents y other digital resources [and bibliography]. < http://www.kb.dk/elib/mss/poma/ > (accessed 04.02.2019).

Hamerly, Michael T.

2011 Artes, Vocabularios, and Related Ecclesiastical Materials of Quichua/Quechua, Aymara, Puquina, and Mochica Published During the Colonial Period. A History and a Bibliography. CD-ROM. Aachen: Shaker. (Bonner Amerikanistische Studien / Estudios Americanistas de Bonn / Bonn Americanist Studies - BAS 48.)

Hatch, Evelyn, and Cheryl Brown

1995 Vocabulary, Semantics, and Language Education. Cambridge: Cambridge University Press. (Cambridge Teaching Library.)

Hoggarth, Leslie

2004 Contributions to Cuzco Quechua Grammar. CD-ROM. Aachen: Shaker Verlag. (Bonner Amerikanistische Studien / Estudios Americanistas de Bonn / Bonn Americanist Studies - BAS 41.)

\section{King James Bible Online}

$2017<$ https://www.kingjamesbibleonline.org/ > (accessed 04.02.2019).

\section{Lafone Quevedo, Samuel}

1892 El culto de Tonapa ... según el Yamqui Pachacuti. Revista del Museo de La Plata, III, 323-379. <

https://ia801402.us.archive.org/28/items/revistadelmuseod03muse/revistad elmuseod03muse.pdf > (accessed 04.02.2019).

Lira, Jorge A.

1944 Diccionario kkechuwa-español. Universidad Nacional de Tucumán, Departamento de Investigaciones Regionales, Instituto de Historia, Lingüística y Folklore, XII. (Universidad Nacional de Tucumán, Publicación no. 369.) 


\section{Mannheim, Bruce}

2008 González Holguín, Diego (1552-1618). In: Joanne Pillsbury (ed.), Guide to Documentary Sources for Andean Studies, 1530-1900; vol. II, 252-254.

National Gallery of Art. Norman, Oklahoma: University of Oklahoma Press.

\section{Mariscotti de Görlitz, Ana María}

1978 Pachamama Santa Tierra. Contribución al estudio de la religión autóctona en los Andes centro-meridionales. Berlin: Gebr. Mann. (Indiana Beiheft 8.)

$<$ http://www.iai.spk-berlin.de/publikationen/estudios-indiana/fruehere-

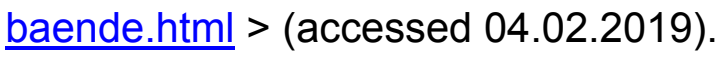

\section{Marzal, Manuel M.}

1971 El mundo religioso de Urcos. Un estudio de antropología religiosa y de pastoral campesina de los Andes. Cuzco: Instituto de Pastoral Andina.

1992

La experiencia religiosa quechua. In: Manuel Marzal, Xavier Albó, and Bartomeu Melià, Rostros indios de Dios; 27-80. La Paz: Centro de Investigación y Promoción del Campesinado (CIPCA); HISBOL; Universidad Católica Boliviana "San Pablo" (UCB).

\section{Merriam Webster Thesaurus}

2018 Springfield, MA: Merriam-Webster Inc. < https://www.merriamwebster.com/thesaurus > (accessed 04.02.2019).

Mills, Kenneth

2008 Provincial Councils. Overview and Commentary. In: Joanne Pillsbury (ed.), Guide to Documentary Sources for Andean Studies, 1530-1900; vol. I, 189196. National Gallery of Art. Norman, Oklahoma: University of Oklahoma Press.

\section{Molina, Cristóbal de}

2010 Relación de las fábulas y ritos de los incas [ca. 1575]. Edición crítica de Paloma Jiménez del Campo; transcripción y paleografía de Paloma Cuenca Muñoz; coordinación de Esperanza López Parada. Frankfurt: Vervuert; Madrid: Iberoamericana. (Parecos y Australes 7.)

Monserrat, Ruth, and Cândida Barros

2018 O primeiro mandamento da lei de deus em confessionários tupi jesuíticos dos séculos XVI e XVII. Article will be published in Indiana (2019).

\section{Muguruza Roca, Isabel}

2018 Del confesionario ibérico de la Contrarreforma a los manuales para confesores en la América colonial: el Manual de confesores y penitentes de Martín de Azpilcueta como texto de referencia. Indiana 35/2: 39-52. < 
https://journals.iai.spk-berlin.de/index.php/indiana/article/view/2526 > (accessed 04.02.2019).

\section{Nachtigall, Horst}

1975 Ofrendas de llamas en la vida ceremonial de los pastores. Allpanchis 8: 133-140.

\section{New Jerusalem Bible}

2015 In: Catholic Online. < http://www.catholic.org/bible/ > (accessed 04.02.2019).

\section{Ondegardo}

see Polo de Ondegardo

Perroud, Pedro C., and Juan M. Chouvenc

¿1969? Diccionario castellano kechwa, kechwa castellano: Dialecto de Ayacucho. Santa Clara, Perú: Seminario ... Padres Redentoristas.

\section{Polo de Ondegardo, Juan}

1985a Instrvccion contra las cerimonias, y ritos que vsan los indios conforme al tiempo de su infidelidad [1585a]. In: Tercer Concilio Provincial de Lima (ed.) 1985: 253-262.

[Anonymous, ascribed to Polo de Ondegardo.]

1985b Los errores y svpersticiones de los indios sacadas del tratado y aueriguacion que hizo el licenciado Polo [1585b]. In: Tercer Concilio Provincial de Lima (ed.) 1985: 265-283. [Also in: < https://archive.org/details/confessionariopa00cath $>$ (accessed 04.02.2019).]

[Text written at the latest in 1567.]

\section{Rodríguez, Pedro}

1998

El Catecismo Romano ante Felipe II y la Inquisición española. Los problemas de la introducción en España del Catecismo del Concilio de Trento. Madrid: RIALP.

\section{Santo Tomás, Domingo de}

1951

Lexicon, o vocabulario de la lengua general del Perú [Valladolid 1560]. [Facsimile.] Lima: Instituto de Historia, Universidad Nacional Mayor de San Marcos.

\section{Senorninchik [sic] Jesucristopa Musuq Testamenton}

1958 Lima: Sociedades Bíblicas Unidas.

\section{Señorninchis Jesucristoq Mosoq Rimanakuynin}

1966 El Nuevo Testamento en quechua del Cuzco y en español (versión popular). Lima: Sociedad Bíblica Peruana. 


\section{Serna Arnaiz, Mercedes}

2006 La tradición humanística en el Inca Garcilaso de la Vega. In: Biblioteca Virtual Universal. < http://www.biblioteca.org.ar/libros/134605.pdf > (accessed 04.02.2019).

\section{Tercero Cathecismo [1585]}

1985 In: Tercer Concilio Provincial de Lima (ed.) 1985: 333-778. [Also: < https://openlibrary.org/works/OL15435929W/Tercero cathecismo y exposi cion de la doctrina christiana por sermones $>$ or < https://ia600302.us.archive.org/12/items/tercerocathecism00cath/tercerocat hecism00cath.pdf > (accessed 04.02.2019).]

[This is a collection of sermons.]

Tercer Concilio Provincial de Lima (ed.)

1985 Doctrina Christiana y catecismo para instrvccion de indios .... [y] Tercero Cathecismo ... [y otros textos]. [Ciudad de los Reyes (Lima): Antonio Ricardo 1584/85]. [Facsímile del texto trilingüe (del ejemplar de la Biblioteca Diocesana de Cuenca).] Madrid: Consejo Superior de Investigaciones Científicas. (Corpus Hispanorum de Pace, vol. 26-2.)

The Lamb of God

1972 Juan Gerson. Sotocoro, Temple of the Franciscan Ex-Convent of La Asunción de Nuestra Señora, Tecamachalco, Puebla, Mexico [1562]. Photo Source: Carrillo Azpeitia, Rafael (1972) Juan Gerson, Pintor Indígena del Siglo XVI. Símbolo de Mestizaje. México, Fondo Editorial de la Plástica Mexicana, 1972. At: PESCCA, Correspondence Credit. Camelo Arredondo et al. 1964 and Niedermeier 2002. At: Project on the Engraved Sources of Spanish Colonial Art (PESSCA), Item 800B. < http://colonialart.org/artworks/800B/artwork zoom > (accessed 04.02.2019).

\section{WorldCat}

2001-19 < https://www.worldcat.org/ > (accessed 04.02.2019). 